\title{
DNA microarray profiling of genes differentially regulated by the histone deacetylase inhibitors vorinostat and LBH589 in colon
} cancer cell lines

\author{
Melissa J LaBonte ${ }^{1}$, Peter M Wilson ${ }^{1}$, William Fazzone ${ }^{1}$, Susan Groshen², \\ Heinz-Josef Lenz ${ }^{3}$ and Robert D Ladner*1
}

\begin{abstract}
Address: ${ }^{1}$ Department of Pathology Norris Comprehensive Cancer Center, Keck School of Medicine, University of Southern California, Los Angeles, CA, USA, ${ }^{2}$ Department of Biostatistics Core Norris Comprehensive Cancer Center, Keck School of Medicine, University of Southern California, Los Angeles, CA, USA and ${ }^{3}$ Division of Medical Oncology, Norris Comprehensive Cancer Center, Keck School of Medicine, University of Southern California, Los Angeles, CA, USA

Email: Melissa J LaBonte - labonte@usc.edu; Peter M Wilson - pmwilson@usc.edu; William Fazzone - willfazz1@gmail.com; Susan Groshen - groshen@usc.edu; Heinz-Josef Lenz - lenz@usc.edu; Robert D Ladner* - rladner@usc.edu

* Corresponding author

Published: 30 November 2009

BMC Medical Genomics 2009, 2:67 doi:10.1 186/1755-8794-2-67

Received: 19 June 2009

Accepted: 30 November 2009

This article is available from: http://www.biomedcentral.com/I755-8794/2/67

(C) 2009 LaBonte et al; licensee BioMed Central Ltd.

This is an Open Access article distributed under the terms of the Creative Commons Attribution License (http://creativecommons.org/licenses/by/2.0), which permits unrestricted use, distribution, and reproduction in any medium, provided the original work is properly cited.
\end{abstract}

\begin{abstract}
Background: Despite the significant progress made in colon cancer chemotherapy, advanced disease remains largely incurable and novel efficacious chemotherapies are urgently needed. Histone deacetylase inhibitors (HDACi) represent a novel class of agents which have demonstrated promising preclinical activity and are undergoing clinical evaluation in colon cancer. The goal of this study was to identify genes in colon cancer cells that are differentially regulated by two clinically advanced hydroxamic acid HDACi, vorinostat and LBH589 to provide rationale for novel drug combination partners and identify a core set of HDACi-regulated genes.
\end{abstract}

Methods: HCTII 6 and HT29 colon cancer cells were treated with LBH589 or vorinostat and growth inhibition, acetylation status and apoptosis were analyzed in response to treatment using MTS, Western blotting and flow cytometric analyses. In addition, gene expression was analyzed using the Illumina Human-6 V2 BeadChip array and Ingenuity ${ }^{\circledR}$ Pathway Analysis.

Results: Treatment with either vorinostat or LBH589 rapidly induced histone acetylation, cell cycle arrest and inhibited the growth of both HCTII6 and HT29 cells. Bioinformatic analysis of the microarray profiling revealed significant similarity in the genes altered in expression following treatment with the two HDACi tested within each cell line. However, analysis of genes that were altered in expression in the HCTII 6 and HT29 cells revealed cell-line-specific responses to HDACi treatment. In addition a core cassette of I I genes modulated by both vorinostat and LBH589 were identified in both colon cancer cell lines analyzed.

Conclusion: This study identified HDACi-induced alterations in critical genes involved in nucleotide metabolism, angiogenesis, mitosis and cell survival which may represent potential intervention points for novel therapeutic combinations in colon cancer. This information will assist in the identification of novel pathways and targets that are modulated by $\mathrm{HDACi}$, providing muchneeded information on HDACi mechanism of action and providing rationale for novel drug combination partners. We identified a core signature of II genes which were modulated by both vorinostat and LBH589 in a similar manner in both cell lines. These core genes will assist in the development and validation of a common gene set which may represent a molecular signature of HDAC inhibition in colon cancer. 


\section{Background}

Within the cellular microenvironment, regulation of gene expression can occur post-transcriptionally through modification of histones and non-histone proteins by acetylation, phosphorylation, methylation, ubiquitination and sumoylation. Two distinct families of enzymes, histone acetyltransferases (HAT) and histone deacetylases (HDAC), work in concert by performing opposing functions to maintain a tightly regulated pattern of acetylation homeostasis. HDACs are zinc-dependent hydrolases which can be classified into 4 different families (class I, IIa, IIb, and IV) that are involved in the remodeling of chromatin by deacetylation of specific lysine residues on histone tails [1,2]. The action of HDACs occurs through formation of large multi-protein complexes with co-activating, co-repressing, and chromatin-remodeling proteins.

It has further been demonstrated that the actions of HDACs and the resultant deacetylation of specific lysine residues is not limited to histones, but occurs on non-histone proteins such as $\alpha$-tubulin, Hsp90, gluccocorticoid receptors, DNA methyltransferase 1 (DNMT 1) and multiple transcription factors (p53, E2F, GATA1, TFIIE and TFIIF) [3-5]. As such, the role of HDACs in the regulation of cellular processes is more complex than first thought, extending far beyond regulating gene expression and involving active roles in cell-cycle-related processes [6-8]. It is therefore not surprising that dysregulation of HDAC and HAT activity has been identified and reported to contribute to the progression of a number of cancers including leukemia, lymphoma, gastric, prostate, breast and colon [9-13].

Multiple HDAC inhibitors (HDACi) have been developed to date and their administration results in the acetylation of both histone and non-histone proteins, leading to the modulation of between 2 and 10\% of expressed genes [14]. The classes of compounds identified as HDACi include: short-chain fatty acids (such as valproic acid), hydroxamic acids (such as TSA, PXD101, LBH589 and vorinostat), cyclic tetrapeptides (such as depsipeptide, FK228) and benzamides (such as MS-275) [15]. Mechanistically, HDACi have been shown to induce G1 and G2/ $\mathrm{M}$ cell cycle arrest, promote differentiation, induction of apoptotic signaling cascades, mitotic failure, polyploidy and increased generation of reactive oxygen species [1618]. The hydroxamic acid-based HDACis, vorinostat (SAHA, Merck) [19,20] and LBH589 (panobinostat, Novartis) [21] are pan-inhibitors of class I and II HDACs that have demonstrated potent cytotoxicity in vitro against a variety of solid tumor cell lines. Vorinostat is currently FDA-approved for the treatment of cutaneous T-cell lymphoma (CTCL) and is currently in clinical investigation for mesothelioma, non-small cell lung cancer and colon cancer. LBH589 is also under extensive clinical investigation in CTCL and a variety of solid tumors.

Colorectal cancer is the third most commonly diagnosed cancer in both men and women in the United States with a predicted 147,000 new cases in 2009 [22]. Although chemotherapy response rates and patient overall survival rates have improved in recent years [23,24], effective colon cancer treatment is hindered by the high occurrence of drug resistance, subsequent treatment failure and patient mortality, resulting in a critical need to identify and exploit novel therapeutic targets and drug combinations to improve clinical efficacy. HDACi have demonstrated potent activity against colon cancer cell lines in vitro and in xenograft models $[15,25,26]$ with little or no cytotoxicity reported against normal cells and clinical evaluations thus far have demonstrated favorable toxicity profiles $[27,28]$.

Several studies to date have demonstrated that HDACi induce alterations in the expression of multiple drug targets and/or metabolic pathways that are critical molecular determinants for cancer therapeutics. Importantly combination treatment with additional agents targeting these modulated pathways has resulted in synergistic growth inhibitory effects on cancer cells in vitro and in vivo. It has been recently reported that HDACi synergize with 5-FU in vitro and in vivo in colon cancer cell line models through HDACi-induced downregulation of the 5-FU target enzyme thymidylate synthase (TS), providing a mechanistic basis for the drug synergy $[25,29]$. The HDACi vorinostat is also reported to acetylate and markedly reduce the chaperone activity of HSP90 in T-cell lymphoma models resulting in a synergistic interaction with the HSP90 inhibitor bortezomib [30]. This combination was subsequently extended to colon cancer cell lines with similar synergistic anti-proliferative effects [31]. In addition, the HDACi vorinostat was demonstrated to induce tumor cell-selective expression of the TRAIL death receptors 4 and 5 sensitizing breast cancer xenografts to the effects of a TRAIL-agonistic antibody [32], an observation which is currently being clinically evaluated in lymphoma patients. More recently, HDACi were also reported to enhance the apoptotic effects of EGFR inhibitors in lung cancer models [33,34] and clinical evaluation of this is ongoing. Therefore, the identification of novel genes modulated by HDACi in colon cancer cells may provide pathway-driven rationale for novel and urgently needed efficacious drug combinations.

This study was designed to determine the effects of two clinically relevant HDACi, vorinostat and LBH589 on the growth characteristics of two cytogenetically distinct colon cancer cell line models HCT116 and HT29. In addition, HDACi-induced alterations in global gene expres- 
sion were analyzed using the Illumina Human-6 V2 BeachChip arrays and Ingenuity ${ }^{\circledast}$ Pathway Analysis.

\section{Methods}

\section{Compounds and Reagents}

LBH589 was provided by Novartis Pharmaceuticals (East Hanover, NJ). Vorinostat was provided by Merck and Co., Inc. (Whitehouse Station, NJ) and the National Cancer Institute (Bethesda, MD). CellTiter ${ }^{96}$ AQueous MTS reagent was purchased from Promega (Madison, WI).

\section{Cell Lines}

HCT116 colon cancer cells were a generous gift of Prof. Bert Vogelstein (Johns Hopkins University, Balitmore, MD) and HT29 colon cancer cells were purchased from ATCC (Manassas, VA). HCT116 and HT29 cell lines were maintained in McCoy's 5A medium, supplemented with $10 \%$ fetal bovine serum (Lonza, East Rutherford, NJ), penicillin/streptomycin and sodium pyruvate (Invitrogen, Carlsbad, CA). Cells were maintained in a humidified Hepa Class 100 Incubator (Thermo, Waltham, MA) at $37^{\circ} \mathrm{C}$ and $5 \% \mathrm{CO}_{2}$. Cell lines were routinely screened for mycoplasma using the MycoALERT Detection kit (Lonza).

\section{Growth Inhibition Assay}

Cells were seeded in 96 well plates at $3 \times 10^{3}$ cells/well in $100 \mu \mathrm{l}$ of growth media and treated with the indicated concentrations of drug for $72 \mathrm{~h}$ at $37^{\circ} \mathrm{C}$ with $5 \% \mathrm{CO}_{2}$. MTS (3-(4,5-dimethylthiazol-2-yl)-5-(3-carboxymethoxyphenyl)-2-(4-sulfophenyl)-2H- tetrazolium), assay (Promega) was performed as previously described [35]. Growth inhibition was measured by comparing A490 of drug-treated cells to that of untreated controls set at $100 \%$. The $\mathrm{IC}_{50}$ value was calculated from sigmoidal doseresponse curves using Prism 5.0 (GraphPad, San Diego, CA). Statistical significance of $\mathrm{IC}_{50}$ values between cell lines was evaluated by ANOVA using SAS 9.3.1 statistical software (Cary, NY).

\section{Flow Cytometric/Sub-GI Analysis}

Cells were seeded at $2.5 \times 10^{5}$ cells/well in 6-well plates. Duplicate wells were treated with the indicated concentration of drug for $24 \mathrm{~h}$ and harvested as previously described [25]. Cells were then analyzed using a Coulter ${ }^{\circledR}$ EPICS $^{\circledast}$ ELITE flow cytometer (Beckman Coulter, Fullerton, CA) equipped with a $15 \mathrm{~mW}$ Argon laser (excitation beam $488 \mathrm{~nm}$ ). Viable cells were gated on a dot plot display of forward scatter versus side scatter to eliminate cell doublets. Cell cycle populations were quantified using histogram analysis software (Expo32, Beckman Coulter). Cells with DNA content $<1$ were considered apoptotic.

\section{Western Blotting}

Following treatment with indicated concentrations of drug for specified time points, Western blot was per- formed as described previously [36]. Acetylated histones were detected using anti-acetyl-H3 and anti-acetyl-H4 rabbit antibodies (Upstate). Monoclonal anti-Poly (ADPRibose) Polymerase (PARP) was obtained from Cell Signaling (Danvers, MA). Secondary antibodies goat-antimouse HRP or goat-anti-rabbit HRP were purchased from Santa Cruz Biotechnology (Santa Cruz, CA). Anti- $\beta$-actin was purchased from Sigma (St. Louis, MO) and used to control for loading.

\section{Microarray Drug Treatments and RNA Isolation}

HCT116 and HT29 colon cancer cells were seeded at $7 \times$ $10^{6}$ cells $/ 10 \mathrm{~cm}$ plate and treated with either $50 \mathrm{nM}$ $\mathrm{LBH} 589$ or $2 \mu \mathrm{M}$ vorinostat for $24 \mathrm{~h}$ at $37^{\circ} \mathrm{C}$ and $5 \% \mathrm{CO}_{2}$. All treatments were conducted in triplicate and fresh medium was added to untreated control cells. Following the $24 \mathrm{~h}$ incubation, cells were harvested and RNA was isolated using the RNeasy ${ }^{\circledast}$ Mini Kit (Qiagen, Valencia, $\mathrm{CA}$ ) according to the manufacturer's protocol. RNA was subjected to lithium chloride precipitation to remove any possible genomic DNA contamination. The integrity of the RNA was analyzed by spectrophotometry and capillary electrophoresis.

\section{Microarray Expression Profiling}

Microarray expression profiling was performed by the USC/Norris Cancer Center Genomics Core Facility (Los Angeles, CA). The RNA was amplified into cRNA and biotinylated by in vitro transcription using the Illumina ${ }^{\circledR}$ TotalPrep RNA Amplification Kit (Ambion, Applied Biosystems, Foster City, CA) according to the manufacturer's protocol. Biotinylated cRNAs were purified, fragmented, and subsequently hybridized to an Illumina Human-6 V2 BeadChip (Illumina, San Diego, CA).

\section{Data normalization and statistical analysis}

Microarray statistical analysis was performed with the assistance of Asuragen Inc., (Austin, TX). The background subtraction, expression summary, normalization, and log base 2 transformation of gene signals were carried out using Quantile Normalization [37]. For statistical analysis, one-way ANOVA was used for multiple group comparison across all samples in the experiment, followed by multiple testing correction to determine the false discovery rate (FDR; Benjamini and Hochberg method [38]). Genes with a FDR-adjusted $p$-value of $<0.05$ were considered statistically significant and termed differentially expressed genes (DEGs). Pair-wise comparisons were then performed for all DEGs. For each pair of treatments, a two-sample $t$-test was carried out for every gene, followed by multiple testing correction to determine FDR. The resulting list of genes and associated $p$-values were graphically represented by hierarchical clustering, Venn analysis, principal components analysis (not shown), and volcano plots (not shown). 


\section{Ingenuity ${ }^{\circledR}$ Pathway Analysis (IPA)}

In the HCT116 and HT29 cancer cell lines, a total of 3043 and 2232 differentially expressed genes respectively that had FDR-adjusted $(p<0.05)$ were used for the pathway analysis. Gene reference accession numbers were imported into the Ingenuity ${ }^{\circledR}$ Pathway Analysis (IPA) software (Ingenuity ${ }^{\circledR}$ Systems, http://www.ingenuity.com, Mountain View, CA). In the HCT116 and HT29 cancer cell lines, 2289 and 1679 of these genes respectively were mapped to the Ingenuity database. Up- and down-regulated genes were both included as a defined parameter for the core analysis. Genes mapped to genetic networks, were then ranked by a score that defines the probability that a collection of genes equal to or greater than the number in a network can be achieved by chance alone. According to IPA, a score of 3 indicates that there is a 1/ 1000 chance that the focus genes are in a network due to random chance, and therefore, scores of $>3$ have a $99.9 \%$ confidence of not being generated by random chance alone. This score was used as the cut-off for identifying gene networks that were significantly affected by the HDACi, LBH589 and vorinostat. In a similar way, DEGs were mapped to canonical pathways and tested by the Fishers Exact Test $p$-value. Canonical pathways were represented as a histogram of pathway vs. $-\log (p$-value $)$. In addition, for canonical pathways a ratio value was calculated as the number of molecules in a given pathway that meet the cut criteria, divided by the total number of molecules that make up that pathway.

\section{Quantitative real-time PCR}

The abundance of selected transcripts, which had been previously identified by microarray expression profiling at $24 \mathrm{~h}$, was re-evaluated by qPCR at 6, 12, and $24 \mathrm{~h}$. The total RNA was isolated from HCT116 and HT29 colon cancer cells with TRIzol reagent (Invitrogen). RNA (0.5 $\mu \mathrm{g}$ ) was reverse transcribed to cDNA using the Promega Reverse Transcription System according to manufacturers instructions and analyzed using an Applied Biosystems 7500 PCR Detection System (Applied Biosystems Inc.). All reactions were performed in triplicate in a final volume of $25 \mu \mathrm{l}$. All amplifications were primed by pairs of chemically synthesized 18- to 24-mer olignucleotides designed using freely available primer design software (Primer-BLAST, NCBI) to generate target amplicons of 100-200 bp. Reaction conditions were as follows: Activation at $95^{\circ} \mathrm{C}$ for $10 \mathrm{~min}$ and 40 cycles of denaturation at $95^{\circ} \mathrm{C}$ for $15 \mathrm{~s}$, annealing at $55^{\circ} \mathrm{C}$ for $35 \mathrm{~s}$, and extension at $72^{\circ} \mathrm{C}$ for $45 \mathrm{~s}$. Melt curve analysis of all samples was routinely performed to ascertain that only the expected products had been generated. All primers utilized displayed PCR efficiencies of $>90 \%$. Target genes were normalized to GAPDH and quantified using the comparative $C_{\mathrm{T}}$ method described by Livak et al. [39] and as used previously [36]. Histograms and statistical analyses (2-tailed unpaired $t$-test) were performed with Prism 5.0 (GraphPad Software).

\section{Results \\ Vorinostat and LBH589 inhibit the growth of colon cancer cells}

The HCT116 and HT29 cell lines were originally derived from human colon adenocarcinomas, and were selected in this study based on marked differences in their cytogenetics. Specifically, these cell lines differ in a number of key genes which have been reported to determine response to chemotherapeutics including the presence of mutant p53 in HT29 cells and activating k-ras and $\beta$-catenin mutations in the HCT116 cells. In addition, HCT116 cells display a near-diploid karyotype while HT29 cells exhibit hyper triploidy. These cell lines were initially analyzed to determine the effects of vorinostat and LBH589 on cellular proliferation. Cells were exposed to increasing concentrations of each drug for $72 \mathrm{~h}$ and subsequently analyzed by MTS assay. The $\mathrm{IC}_{50(72 \mathrm{~h})}$ values for LBH589 in the HCT116 and HT29 colon cancer cells were in the low nanomolar range at $3.49 \mathrm{nM}(95 \%$ CI 3.1 - $3.9 \mathrm{nM})$ and $9.8 \mathrm{nM}(95 \% \mathrm{CI} 8.7$ - $10.9 \mu \mathrm{M})$ respectively (Figure $1 \mathrm{~A})$. The $\mathrm{IC}_{50(72 \mathrm{~h})}$ values for vorinostat in the HCT116 and HT29 cells were in the low micromolar range at $1.06 \mu \mathrm{M}$ (95\% CI $0.94-1.1 \mu \mathrm{M}$ ) and $1.56 \mu \mathrm{M}$ (95\% CI $1.45-1.67$ $\mu \mathrm{M})$ respectively (Figure $1 \mathrm{~B})$. The HCT116 cells demonstrated a $>2$-fold increase in sensitivity to LBH589 ( $p=$ $0.0019)$ and a 1.5 -fold increase in sensitivity to vorinostat ( $p=0.027)$ over the HT29 cells.

\section{HDACi treatment rapidly induces histone acetylation}

Inhibition of HDACs results in disruption of cellular acetylation homeostasis and can induce hyper-acetylation of both histone and non-histone proteins. In order to examine this effect in our colon cancer cell line models, we treated cells with either $2 \mu \mathrm{M}$ vorinostat or $50 \mathrm{nM}$ LBH589 and analyzed the acetylation status of selected histone proteins. As histone acetylation is reported to be a rapid event following HDACi treatment we analyzed the expression of acetyl-H3 (Ac-H3) and acetyl-H4 (Ac-H4) from 0.5 to $4 \mathrm{~h}$ post-treatment. In HCT116 cells, treatment with $2 \mu \mathrm{M}$ vorinostat resulted in significant Ac-H4 at $2 \mathrm{~h}$ post-treatment, however $50 \mathrm{nM}$ LBH589 induced modest but detectable Ac-H4 as early as 0.5 and 1 h posttreatment which increased significantly at 2 and $4 \mathrm{~h}$ (Figure $1 \mathrm{C}$ and $1 \mathrm{D})$. Interestingly, $\mathrm{Ac}-\mathrm{H} 3$ was detected as early as $0.5 \mathrm{~h}$ post-treatment with both HDACi and increased in a time-dependent manner. In HT29 cells, an increase in Ac-H4 was not detectable following treatment with both HDACi until $4 \mathrm{~h}$ post-treatment (Figure 1D). In contrast, Ac-H3 was detected at low levels as early as $0.5 \mathrm{~h}$ posttreatment with levels remaining consistent until $4 \mathrm{~h}$ posttreatment where a marked increase in Ac-H3 was observed. These results demonstrate that HDACi treat- 
A

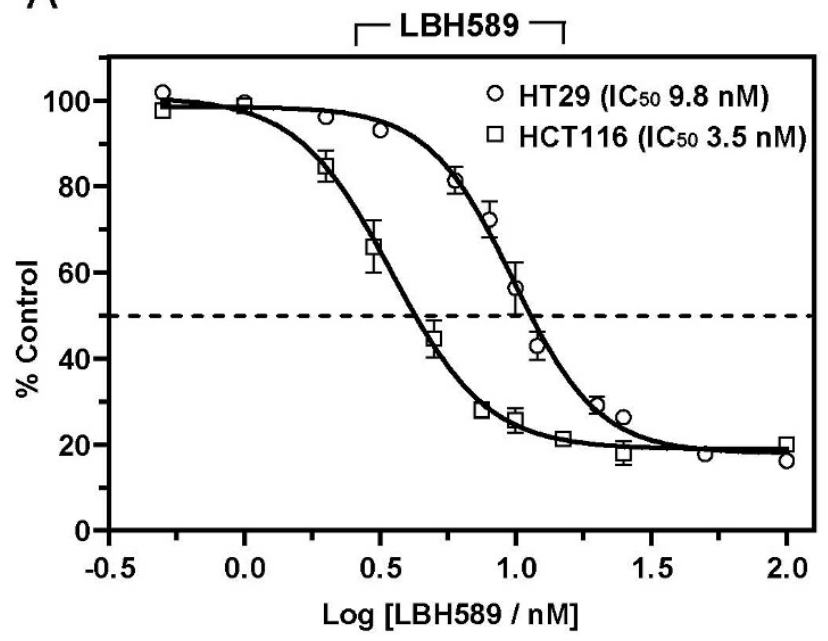

C
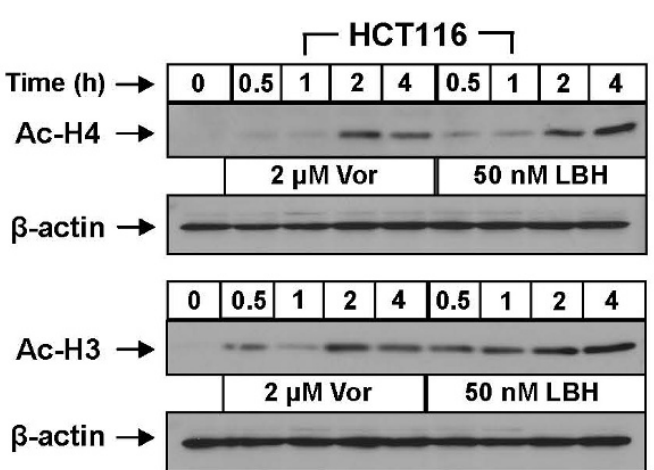

B

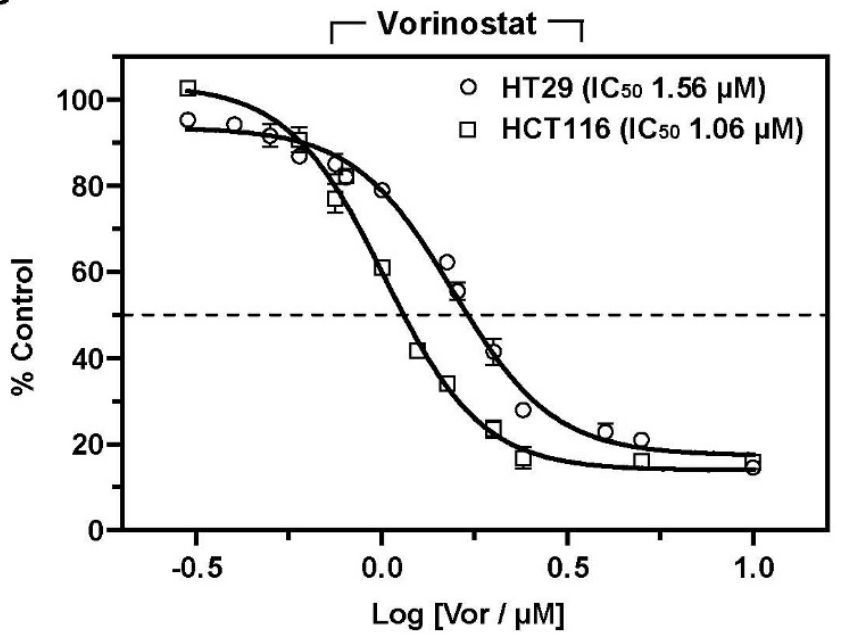

D

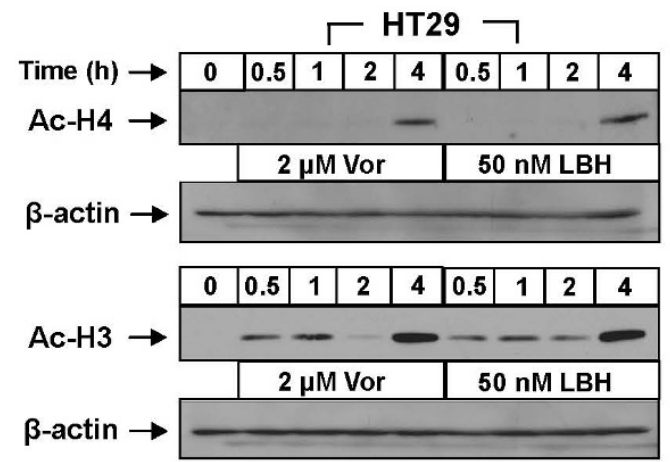

Figure I

In vitro characterization of HDACi, LBH589 and vorinostat, in HCT I 16 and HT29 colon cancer cells. HCTI I6 and HT29 colon cancer cells were exposed to increasing concentrations of either (A) LBH589 or (B) vorinostat alone for 72 $\mathrm{h}$ and subsequent growth inhibition was measured by MTS assay (Promega). Values are presented as percent control, calculated from the growth inhibition induced by a given concentration of drug compared to the untreated control. Values are averages of 3 independent experiments \pm SEM. The $I_{50(72 h)}$ values were calculated from the sigmoidal dose-response curves in Prism 5.0 (GraphPad). (C-D) Western blot analysis of acetyl-H3 and acetyl-H4 in (C) HCTII6 and (D) HT29 cells treated with $2 \mu \mathrm{M}$ vorinostat (Vor) or $50 \mathrm{nM} \mathrm{LBH589}$ for $0.5, \mathrm{I}, 2$ and $4 \mathrm{~h}$. $\beta$-actin was used to control for loading.

ment has detectable and measurable effects on histone acetylation in colon cancer cells within 30 minutes of drug treatment.

\section{HDACi-induce cell cycle arrest and apoptosis}

HDACi are reported to rapidly induce cell cycle arrest and induce tumor cell-selective apoptosis. To investigate this, flow cytometry was subsequently utilized to examine the effects of HDACi treatment on cell cycle distribution in HCT116 and HT29 colon cancer cells. Each cell line was treated with $50 \mathrm{nM}$ LBH589 and $2 \mu \mathrm{M}$ vorinostat (concentrations which were shown to induce similar patterns of histone acetylation) for $24 \mathrm{~h}$ and DNA content was subsequently analyzed by propidium iodide staining. The HCT116 colon cancer cells treated with either HDACi,
LBH589 or vorinostat, displayed a significant G2/M arrest accompanied by a sharp reduction of cells in G1. Interestingly, cells with subdiploid DNA content (Sub-G1), indicative of cell death, increased from $2 \%$ in untreated controls to 30.2 and $34.4 \%$ following treatment with LBH589 and vorinostat respectively (Figure 2A). In HT29 cells, treatment with vorinostat resulted in an accumulation of cells arresting in G1 accompanied by a reduction of cells in both G2 and S. Interestingly, LBH589 induced a G2 arrest with a reduction of cells in G1 and S phases (Figure 2B). Despite displaying a similar $\mathrm{IC}_{50(72 \mathrm{~h})}$ value for vorinostat to that of the HCT116 cells, HT29 cells showed only a modest increase in cell death from $2 \%$ to $9.5 \%$ following treatment with vorinostat. Similarly, despite the concentration of LBH589 being in excess of 
A

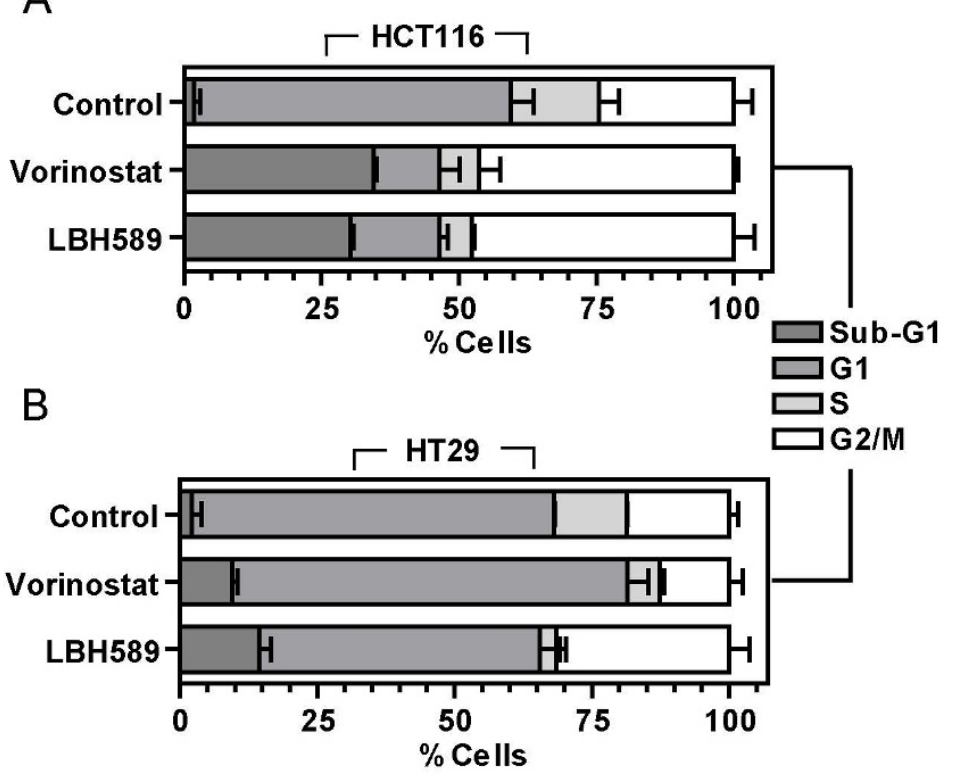

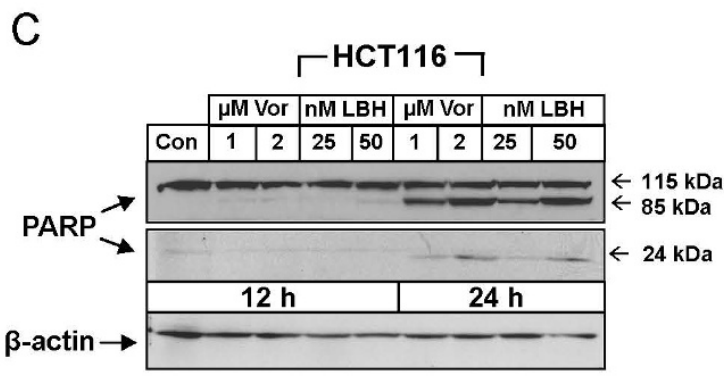

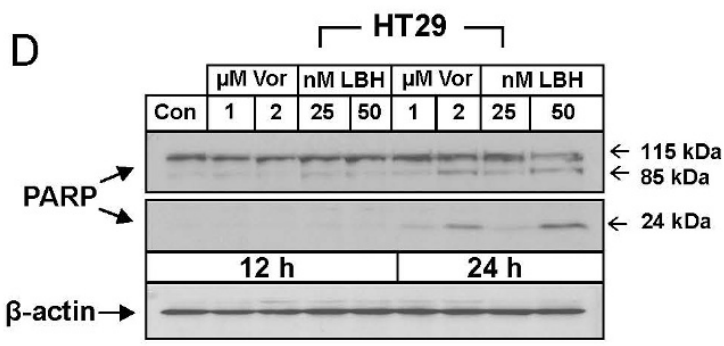

Figure 2

Cell cycle and apoptotic anlaysis of HDACi-treated colon cancer cells. Flow cytometric analysis of (A) HCTI I6 and (B) HT29 cells treated with $2 \mu \mathrm{M}$ vorinostat (Vor) or $50 \mathrm{nM}$ LBH589. Histogram bars represent mean \pm SEM. (C-D) Western blot analysis of poly (ADP-ribose) polymerase (PARP) cleavage as a measure of the induction of apoptosis in HCTII6 and HT29 cells treated with I and $2 \mu \mathrm{M}$ vorinostat or 25 and $50 \mathrm{nM} \mathrm{LBH589}$ for 12 and $24 \mathrm{~h}$. $\beta$-actin was used to control for loading.

the $\mathrm{IC}_{50(72 \mathrm{~h})}$ value for HT29 cells, cell death increased modestly from $2 \%$ to $14.4 \%$ (Figure $2 \mathrm{~B}$ ). These data suggest that while both cell lines display similar sensitivity to the growth inhibitory effects of HDACi, the HT29 cells are significantly more resistant to the onset of HDACiinduced apoptosis in this time-frame. To confirm these differential levels of HDACi-induced apoptosis, HCT116 and HT29 cells were analyzed for the cleavage of poly (ADP-ribose) polymerase (PARP) (a hallmark of apoptosis) from its native $115 \mathrm{kDa}$ to the $89 \mathrm{kDa}$ subunit by Western blot. Compared to vehicle-treated cells, HCT116 cells displayed strong dose-dependent cleavage of PARP at $24 \mathrm{~h}$ post treatment evidenced in particular by the strong immunoreactivity of the $85 \mathrm{kDa}$ subunit when compared to the full length PARP (Figure 2C). Twenty-four h posttreatment, PARP cleavage was detected at low levels in HT29 cells in a dose-dependent manner as evidenced by the appearance of the cleaved subunits (Figure 2D). These results support the flow cytometric analysis whereby HCT116 are significantly more susceptible to rapid HDACi-induced apoptosis than the HT29 cells.

\section{Microarray profiling in HDACi treated colon cancer cells}

To identify the molecular events which occur in response to HDAC inhibition in colon cancer cells, we treated both HCT116 and HT29 colon cancer cells with the clinically relevant concentrations of $50 \mathrm{nM}$ LBH589 or $2 \mu \mathrm{M}$ vori- nostat for $24 \mathrm{~h}$, isolated mRNA and subsequently analyzed gene expression using the Illumina Human-6 V2 BeadChip array platform as outlined in the methods section. Genes with a FDR-adjusted $p$-value of $<0.05$ were considered differentially expressed genes (DEGs) relative to vehicle treated controls. The heat maps generated from the microarray analysis in HCT116 and HT29 cells treated with HDACi were subject to hierarchical clustering analysis. The heat map demonstrates that both vorinostat and LBH589 segregated independently from the vehicletreated controls in both cell lines. However, the cluster tree generated also demonstrates that while vorinostat and LBH589 segregate from the vehicle-treated controls, they demonstrate very similar clustering patterns indicating that they induce similar transcriptional response within each cell line (Figure 3).

\section{Differentially expressed genes in response to HDACi treatment}

To compare the effects of HDACi treatment relative to vehicle-treated cells, Venn analysis was utilized. In HCT116 cells, a combined total of 3566 genes were modulated by HDACi treatment (both LBH589 or vorinostat) representing approximately $7 \%$ of the total gene set analyzed by the array. Within this set, 3100 DEGs were identified following vorinostat treatment of which 57 genes were uniquely modulated by vorinostat treatment as illus- 


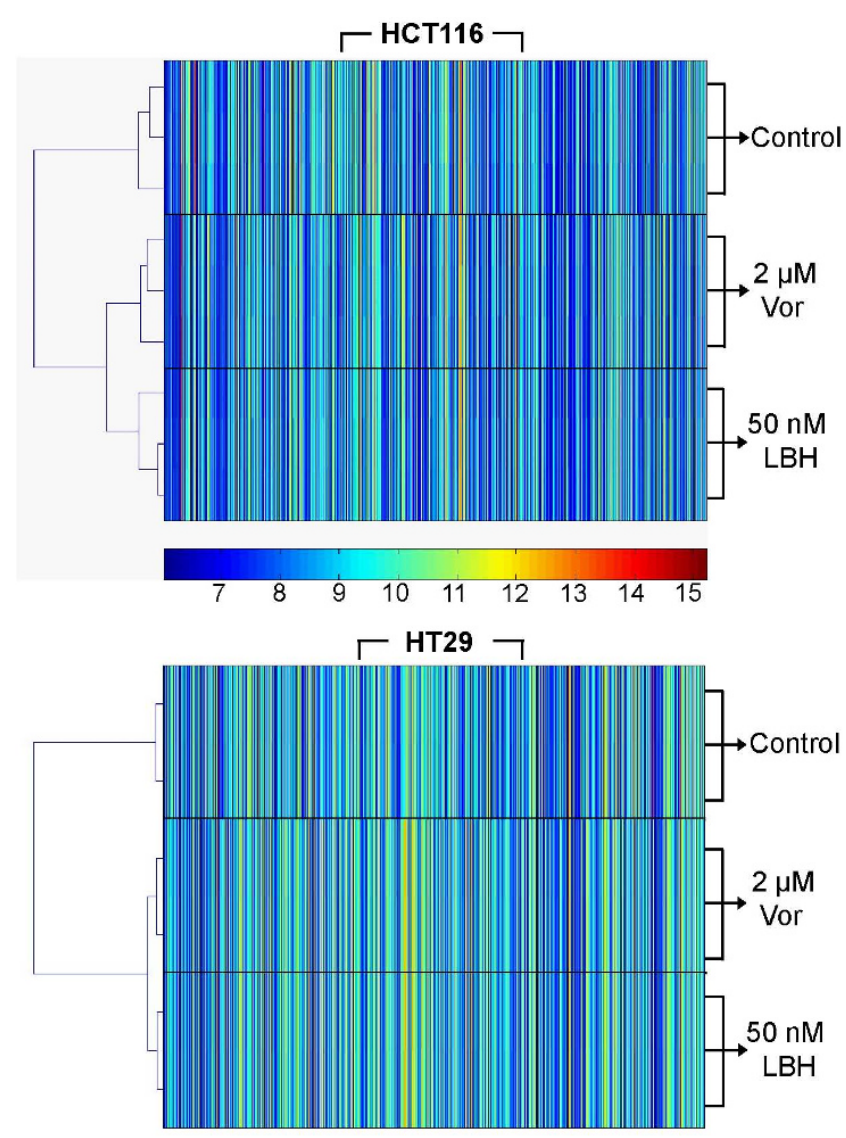

Figure 3

Hierarchical cluster analysis of HDACi-treated HCTII 6 and HT29 colon cancer cells. Cells were treated with $2 \mu \mathrm{M}$ vorinostat or $50 \mathrm{nM} \mathrm{LBH} 589$ for $24 \mathrm{~h}$ and gene expression was analyzed using the Illumina Human-6 V2 BeadChip array. Hierarchical cluster heat map and tree was generated from $\mathrm{HDACi}$-induced changes in gene expression (I-way ANOVA, $\mathrm{p}<0.05)$.

trated by the Venn diagram (Figure 4A). Following treatment with LBH589, 3509 DEGs were identified of which 466 genes were uniquely modulated by LBH589 (Figure 4A). This data demonstrates that in HCT116 cells, vorinostat and LBH589 exert similar effects on gene expression with $85 \%$ of all DEGs modulated in a consistent manner by both vorinostat and LBH589 treatment.

In HT29 cells, 2645 genes were modulated in total by both HDACi representing approximately $5 \%$ of the total gene set analyzed by the array (Figure 4B). Of this total, 2448 genes were modulated by vorinostat of which 216 of these DEGs were unique only to vorinostat treatment (Figure 4B). Following treatment with LBH589, 2429 genes were modulated of which 197 were unique transcriptional responses to LBH589 not observed with vorinostat treatment (Figure 4B). This indicates that there is also significant similarity in the transcriptional changes induced
A

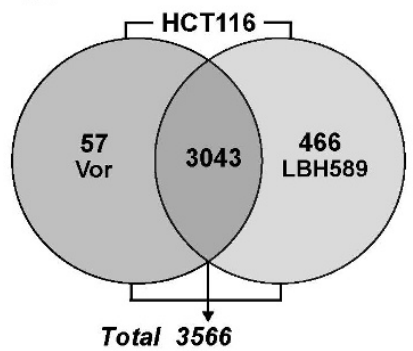

B

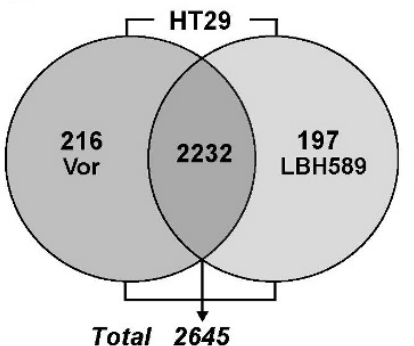

D
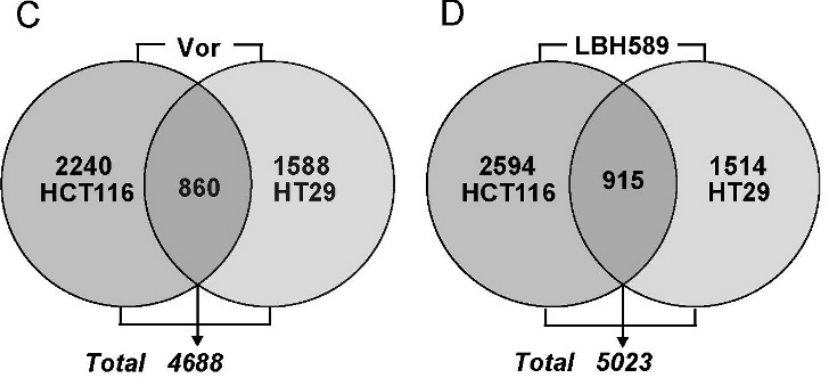

Figure 4

Venn analysis of differentially expressed genes in vorinostat and LBH589-treated HCT 116 and HT29 colon cancer cells. HCTII 6 and HT29 cells were treated with either $2 \mu \mathrm{M}$ vorinostat or $50 \mathrm{nM}$ LBH589 for $24 \mathrm{~h}$ and gene expression analyzed on the Illumina Human-6 V2 BeadChip array. Genes with an FDR-adjusted $p$-value of $<0.05$ were considered differentially expressed and subjected to Venn analysis. Venn analysis was first performed by analyzing cell-line-specific alterations in each individual cell line; (A) HCTI 16 cells treated with vorinostat or LBH589. (B) HT29 cells treated with vorinostat or LBH589. Subsequent Venn analysis demonstrates the drug-specific alterations induced by (C) vorinostat (Vor) and (D) LBH589 in both cell lines. Numbers within each circle represent the total number of genes modulated in that experimental condition, the numbers immediately below each Venn diagram indicate the total number of modulated genes by both experimental conditions in that Venn diagram.

by vorinostat and LBH589 in HT29 cells with $75 \%$ of the total DEG set common transcriptional changes in response to either HDACi.

Of the 3100 DEGs modulated by vorinostat treatment in HCT116 cells, 24 were up-regulated and 17 were downregulated $>2$-fold. Of the 3509 genes modulated following treatment with LBH589 in HCT116 cells, 92 genes were upregulated and 150 were downregulated $>2$-fold. The top 15 up- and downregulated genes modulated $>2$ fold for both vorionostat and LBH589 treatment in HCT116 cells are displayed in Table 1.

Similarly, in HT29 cells, the majority of DEGs were also modulated <2-fold when compared to vehicle-treated controls as was observed in the HCT116 cells. Of the 2448 
Table I: Differentially expressed genes (>2 Fold) in response to HDACi in HCTI I 6 colon cancer cells.

\begin{tabular}{|c|c|c|c|c|}
\hline \multirow[b]{2}{*}{$\begin{array}{l}\text { Accession \# } \\
\text { Induced }\end{array}$} & \multirow[b]{2}{*}{ Gene Symbol } & \multirow[b]{2}{*}{ Gene Name } & \multicolumn{2}{|c|}{ HCTII6 } \\
\hline & & & \multicolumn{2}{|c|}{ LBH589 } \\
\hline NM_001901.2 & CTGF & Connective tissue growth factor & 6.09 & $6.9 \mathrm{E}-04$ \\
\hline NM_I82908.3 & DHRS2 & Dehydrogenase/reductase member 2 & 4.78 & $1.7 \mathrm{E}-04$ \\
\hline NM_003378.2 & VGF & VGF nerve growth factor inducible & 4.74 & $\mathrm{I} .0 \mathrm{E}-04$ \\
\hline NM_183376.I & ARRDC4 & Arrestin domain containing 4 & 4.15 & $6.9 \mathrm{E}-04$ \\
\hline NM_I73798.2 & $\mathrm{ZCCHCI} 2$ & Zinc finger, $\mathrm{CCHC}$ domain containing $\mathrm{I} 2$ & 4.13 & $1.8 \mathrm{E}-05$ \\
\hline NM_006865.2 & LILRA3 & Leukocyte immunoglobulin-like receptor, subfamily A, member 3 & 3.94 & $7.2 \mathrm{E}-05$ \\
\hline NM_033184.2 & KRTAP2-4 & Keratin associated protein $2-4$ & 3.61 & $7.2 \mathrm{E}-04$ \\
\hline NM_000558.3 & HBAI & Hemoglobin, alpha I & 3.60 & $3.2 \mathrm{E}-04$ \\
\hline NM_016352.3 & CPA4 & Carboxypeptidase A4 & 3.47 & 2.7E-04 \\
\hline NM_00I554.4 & CYR6I & Cysteine-rich, angiogenic inducer, 61 & 3.44 & 2.7E-05 \\
\hline NM_005319.3 & HISTIHIC & Histone I, HIC & 3.37 & $9.9 \mathrm{E}-05$ \\
\hline NM_I38720.I & HISTIH2BD & Histone I, H2bd & 3.35 & $2.2 \mathrm{E}-04$ \\
\hline NM_03|476.I & CRISPLD2 & Cysteine-rich secretory protein LCCL domain containing 2 & 3.26 & $8.4 \mathrm{E}-05$ \\
\hline NM_139072.2 & DNER & Delta-notch-like EGF repeat-containing transmembrane & 3.21 & $1.5 \mathrm{E}-03$ \\
\hline NM_00506I.2 & RPL3L & Ribosomal protein L3-like & 3.08 & $2.5 \mathrm{E}-05$ \\
\hline \multicolumn{5}{|l|}{ Repressed } \\
\hline NM_0I3233.2 & STK39 & Serine threonine kinase 39 & -2.91 & $8.2 \mathrm{E}-04$ \\
\hline NM_004091.2 & E2F2 & E2F transcription factor 2 & -2.93 & $2.4 \mathrm{E}-04$ \\
\hline NM_003302.I & TRIP6 & Thyroid hormone receptor interactor 6 & -2.99 & 7.3E-04 \\
\hline NM_005733.2 & KIF20A & Kinesin family member $20 \mathrm{~A}$ & -3.00 & 2.2E-05 \\
\hline NM_005329.2 & HAS3 & Hyaluronan synthase 3 & -3.02 & 4.IE-05 \\
\hline NM_I45810.1 & CDCA7 & Cell division cycle associated 7 & -3.06 & $2.4 \mathrm{E}-03$ \\
\hline NM_005434.4 & MALL & Mal, T-cell differentiation protein-like & -3.07 & $2.8 \mathrm{E}-04$ \\
\hline NM_002I29.2 & HMGB2 & High-mobility group box 2 & -3.13 & $3.6 \mathrm{E}-03$ \\
\hline NM_0I8649.2 & $\mathrm{H} 2 \mathrm{AFY} 2$ & $\mathrm{H} 2 \mathrm{~A}$ histone family, member $\mathrm{Y} 2$ & -3.28 & 8.7E-04 \\
\hline NM_00I038.5 & SCNNIA & Sodium channel, nonvoltage-gated I & -3.59 & $6.6 \mathrm{E}-04$ \\
\hline NM_004217.2 & AURKB & Aurora kinase B & -3.61 & $5.4 \mathrm{E}-04$ \\
\hline NM_00I237.3 & CCNA2 & Cyclin A2 & -3.72 & $2.9 \mathrm{E}-05$ \\
\hline NM_00107I.I & TYMS & Thymidylate synthase & -3.88 & I.IE-04 \\
\hline NM_181803.I & UBE2C & Ubiquitin-conjugating enzyme E2C & -3.95 & 2.6E-04 \\
\hline NM_001423.2 & EMPI & Epithelial membrane protein I & -4.17 & $1.3 \mathrm{E}-05$ \\
\hline Induced & & & \multicolumn{2}{|c|}{ Vorinostat } \\
\hline NM_001901.2 & CTGF & Connective tissue growth factor & 4.76 & $2.0 \mathrm{E}-05$ \\
\hline NM_003378.2 & VGF & VGF nerve growth factor inducible & 4.35 & $1.8 \mathrm{E}-03$ \\
\hline NM_I82908.3 & DHRS2 & Dehydrogenase/reductase member 2 & 4.05 & $6.2 \mathrm{E}-04$ \\
\hline NM_I83376.I & ARRDC4 & Arrestin domain containing 4 & 3.35 & 4.4E-04 \\
\hline NM_I I 73798.2 & $\mathrm{ZCCHCI} 2$ & Zinc finger, $\mathrm{CCHC}$ domain containing 12 & 3.27 & $1.7 \mathrm{E}-06$ \\
\hline NM_016352.3 & CPA4 & Carboxypeptidase A4 & 2.91 & $1.0 \mathrm{E}-03$ \\
\hline NM_0I7445.I & H2BFS & $\mathrm{H} 2 \mathrm{~B}$ histone family, member $\mathrm{S}$ & 2.86 & $2.8 \mathrm{E}-04$ \\
\hline NM_I 38720.1 & HISTIH2BD & Histone I, H2bd & 2.85 & $1.6 \mathrm{E}-04$ \\
\hline NM_033184.2 & KRTAP2-4 & Keratin associated protein $2-4$ & 2.81 & $2.6 \mathrm{E}-03$ \\
\hline NM_00I554.4 & CYR6I & Cysteine-rich, angiogenic inducer, $6 \mathrm{I}$ & 2.73 & $1.3 \mathrm{E}-05$ \\
\hline NM_I39072.2 & DNER & Delta-notch-like EGF repeat-containing transmembrane & 2.62 & $2.2 \mathrm{E}-03$ \\
\hline NM_005319.3 & HISTIHIC & Histone I, HIc & 2.57 & $5.4 \mathrm{E}-04$ \\
\hline NM_006865.2 & LILRA3 & Leukocyte immunoglobulin-like receptor, subfamily A, member 3 & 2.37 & $1.2 \mathrm{E}-03$ \\
\hline NM_005952.2 & MTIX & Metallothionein Ix & 2.37 & $1.2 \mathrm{E}-03$ \\
\hline NM_080593.I & HISTIH2BK & Histone I, H2bk & 2.36 & $9.2 \mathrm{E}-06$ \\
\hline NM_005950.I & MTIG & Metallothionein IG & 2.33 & 7.4E-03 \\
\hline \multicolumn{5}{|l|}{ Repressed } \\
\hline NM_003998.2 & NFKBI & Nuclear factor of kappa light polypeptide gene enhancer in B-cells I (pI05) & -2.04 & $6.9 \mathrm{E}-04$ \\
\hline NM_0I8043.5 & TMEMI6A & Transmembrane protein 16A & -2.05 & $1.6 \mathrm{E}-03$ \\
\hline NM_003302.I & TRIP6 & Thyroid hormone receptor interactor 6 & -2.08 & $6.6 \mathrm{E}-03$ \\
\hline NM_I45810.1 & CDCA7 & Cell division cycle associated 7 & -2.08 & $2.4 \mathrm{E}-03$ \\
\hline NM_004217.2 & AURKB & Aurora kinase B & -2.08 & 1.7E-03 \\
\hline NM_00I235.2 & SERPINHI & Serpin peptidase inhibitor, clade $\mathrm{H}$ (heat shock protein 47 ), member I & -2.11 & 7.4E-05 \\
\hline NM_00I425.2 & EMP3 & Epithelial membrane protein 3 & -2.11 & $1.0 \mathrm{E}-03$ \\
\hline
\end{tabular}


Table I: Differentially expressed genes (>2 Fold) in response to HDACi in HCTI 16 colon cancer cells. (Continued)

\begin{tabular}{|c|c|c|c|c|}
\hline NM_005329.2 & HAS3 & Hyaluronan synthase 3 & -2.11 & $2.4 \mathrm{E}-05$ \\
\hline NM_001237.3 & CCNA2 & Cyclin A2 & -2.15 & $1.5 \mathrm{E}-03$ \\
\hline NM_002129.2 & HMGB2 & High-mobility group box 2 & -2.17 & I.3E-03 \\
\hline NM_005434.4 & MALL & Mal, T-cell differentiation protein-like & -2.17 & 4.2E-04 \\
\hline NM_001423.2 & EMPI & Epithelial membrane protein I & -2.23 & $1.6 \mathrm{E}-04$ \\
\hline NM_I81803.1 & UBE2C & Ubiquitin-conjugating enzyme E2C & -2.31 & 3.IE-04 \\
\hline NM_018649.2 & $\mathrm{H} 2 \mathrm{AFY} 2$ & $\mathrm{H} 2 \mathrm{~A}$ histone family, member $\mathrm{Y} 2$ & -2.51 & $2.2 \mathrm{E}-06$ \\
\hline NM_00107I.I & TYMS & Thymidylate synthase & -2.74 & 7.4E-06 \\
\hline
\end{tabular}

DEGs modulated by vorinostat treatment in HT29 cells, 138 were up-regulated and 53 were down-regulated $>2$ fold. Of the 3509 genes modulated following treatment with LBH589 in HT29 cells, 163 genes were upregulated and 54 were downregulated $>2$-fold. The top 15 up- and downregulated genes for both vorinostat and LBH589 treatment in HT29 cells are displayed in Table 2.

\section{Identification of biological pathways modulated by $\mathrm{HDACi}$} We further analyzed the HDACi-DEGs to explore the key biological pathways modulated by HDACi treatment. We performed pathway analysis using Ingenuity ${ }^{\circledast}$ Pathway Analysis (IPA) on the DEGs in both the HCT116 and HT29 cell lines, treated with LBH589 and vorinostat. In the HCT116 cells, 2289 of the 3043 DEGs and 1679 of the 2232 DEGs in the HT29 cells mapped to defined genetic networks in IPA Knowledge Base. Five networks were found to be altered by HDACi in that they possessed significantly more of the identified DEGs present than would be expected by random chance. These networks included cell cycle; DNA replication, recombination and repair; apoptosis; gene expression and cell growth and proliferation. The mapped DEGs were subsequently analyzed for the top 12 canonical biological pathways that demonstrated significance within each dataset. In HCT116 cells, 5 common pathways were modulated by both HDACi; coagulation system, pyrimidine metabolism, metabolism of xenobiotics, arachidonic acid metabolism and fatty acid metabolism (Figure 5A and 5B). In HT29 cells, 7 common pathways were modulated by both HDACi; arginine and proline metabolism; urea cycle and metabolism of amino groups; arachidonic acid metabolism; fructose and mannose metabolism; pentose phosphotate pathway; nitrogen metabolism and bile acid biosynthesis (Figure 5C and 5D).

\section{Common gene signature of HDAC inhibition in colon cancer cells}

One of the key objectives of this study was to identify a cassette of genes which were consistently regulated by both vorinostat and LBH589 in both cell lines examined. Such a cassette of consistently regulated genes may serve as molecular markers for HDACi treatment in colon cancer cells.
From the Venn analysis, it is apparent that there is significant differences in how the HCT116 and HT29 cells respond to HDACi treatment. Specifically, when HCT116 and HT29 cells were treated with vorinostat, a combined total of 4688 DEGs ( $p$-value $<0.05$ ) were identified. However, of this combined total of 4688 DEGs, only 860 (18.3\%) genes were transcriptional changes common to both cell lines (Figure 4C and 4D). Similarly, in both cell lines a combined total of 5023 DEGs ( $p$-value < 0.05) were identified following treatment with LBH589. However, of these 5023 DEGs, only 915 (18.2\%) were transcriptional changes common to both cell lines (Figure 4C and 4D). From this overlapping gene list, up- and downregulated genes in the HCT116 and HT29 cells were directly compared using a 1.5-fold cutoff. From this comparative list, we identified a panel of 11 genes, 6 genes that are significantly upregulated and 5 that are downregulated in a consistent manner in both cell lines by treatment with both HDACi (Table 3).

\section{Verification of microarray results by quantitative real-time RT-PCR}

In order to assess the robustness of the microarray analysis, quantitative real-time RT-PCR (qPCR) analysis was performed to validate a selected panel of 15 DEGs and 2 non-DEGs [39], using the primer sets given in Table 4. qPCR was performed on cDNA generated using RNA independently isolated from HCT116 and HT29 treated with either $2 \mu \mathrm{M}$ vorinostat or $50 \mathrm{nM}$ LBH589. Due to the pleotropic effects on gene expression induced by HDACi, we first confirmed that our selected qPCR normalizing gene was not modulated by HDACi treatment in either cell line prior to DEG verification. We selected 2 house-keeping genes, 18s rRNA and GAPDH, whose expression was unchanged in the microarray analysis (non-DEGs) and confirmed using qPCR that these genes retained consistent expression during HDACi treatment (Figure 6A). GAPDH was subsequently used to normalize all qPCR data. To further validate and characterize the DEGs identified by the microarray analysis, we analyzed the timedependent change in expression of the selected DEGs at 6 , 12 and 24 hours post-HDACi treatment when compared to vehicle-treated time-matched controls. The pattern of expression obtained for 14 of the 15 selected DEGs $24 \mathrm{~h}$ post-treatment showed consistent directional conforma- 
Table 2: Differentially expressed genes (>2 Fold) in response to HDACi in HT29 colon cancer cells.

\begin{tabular}{|c|c|c|c|c|}
\hline \multirow[b]{2}{*}{$\begin{array}{l}\text { Accession \# } \\
\text { Induced }\end{array}$} & \multirow[b]{2}{*}{ Gene Symbol } & \multirow[b]{2}{*}{ Gene Name } & \multicolumn{2}{|c|}{ HT29 } \\
\hline & & & $\begin{array}{r}\text { Fold Change } \\
\text { LBH5 }\end{array}$ & 9 -Value \\
\hline NM_002305.2 & LGALSI & Lectin, galactoside-binding soluble I & 5.22 & 3.0E-03 \\
\hline NM_003088.2 & FSCNI & Fascin homolog I, actin-bundling protein & 5.06 & $5.6 \mathrm{E}-03$ \\
\hline NM_006262.3 & $\mathrm{PRPH}$ & Peripherin & 4.58 & $9.8 \mathrm{E}-04$ \\
\hline NM_004223.3 & UBE2L6 & Ubiquitin-conjugating enzyme E2L 6 & 4.58 & $9.7 \mathrm{E}-04$ \\
\hline NM_I82908.3 & DHRS2 & Dehydrogenase/reductase member 2 & 4.37 & $5.5 \mathrm{E}-03$ \\
\hline NM_006086.2 & TUBB3 & Tubulin, beta 3 & 4.06 & $1.4 \mathrm{E}-02$ \\
\hline NM_002084.2 & GPX3 & Glutathione peroxidase 3 & 4.05 & $5.2 \mathrm{E}-03$ \\
\hline NM_I53247.I & SLC29A4 & Solute carrier family 29, member 4 & 3.92 & I.IE-03 \\
\hline NM_003283.3 & TNNTI & Troponin T type I & 3.92 & $1.3 \mathrm{E}-03$ \\
\hline NM_I780I2.3 & TUBB2B & Tubulin, beta $2 \mathrm{~B}$ & 3.92 & $3.4 \mathrm{E}-03$ \\
\hline NM_00I928.2 & CFD & Complement factor D (adipsin) & 3.87 & $5.4 \mathrm{E}-03$ \\
\hline NM_006117.2 & $\mathrm{PECl}$ & Peroxisomal D3, D2-enoyl-CoA isomerase & 3.83 & $6.8 \mathrm{E}-03$ \\
\hline NM_005319.3 & HISTIHIC & Histone I, HIc & 3.78 & $1.3 \mathrm{E}-03$ \\
\hline NM_005952.2 & MTIX & Metallothionein IX & 3.66 & $5.9 \mathrm{E}-03$ \\
\hline NM_0I7707.2 & DDEFLI & Development and differentiation enhancing factor-like I & 3.60 & $6.6 \mathrm{E}-04$ \\
\hline \multicolumn{5}{|l|}{ Repressed } \\
\hline NM_206963.I & RARRESI & Retinoic acid receptor responder I & -2.41 & $\mathrm{I} .0 \mathrm{E}-02$ \\
\hline NM_00103I733.I & CALML4 & Calmodulin-like 4 & -2.42 & I.IE-03 \\
\hline NM_007I67.2 & ZMYM6 & Zinc finger, MYM-type 6 & -2.43 & $8.8 \mathrm{E}-03$ \\
\hline NM_002423.3 & MMP7 & Matrix metallopeptidase 7 & -2.55 & 7.IE-03 \\
\hline NM_0809II.I & UNG & Uracil-DNA glycosylase & -2.58 & I.IE-02 \\
\hline NM_I45810.I & CDCA7 & Cell division cycle associated 7 & -2.59 & $2.0 \mathrm{E}-03$ \\
\hline NM_006169.2 & NNMT & Nicotinamide N-methyltransferase & -2.61 & $4.4 \mathrm{E}-03$ \\
\hline NM_02037I.2 & AVEN & Apoptosis, caspase activation inhibitor & -2.66 & $4.3 \mathrm{E}-04$ \\
\hline NM_005375.2 & MYB & V-myb myeloblastosis viral oncogene homolog & -2.72 & $1.2 \mathrm{E}-03$ \\
\hline NM_0528I3.2 & CARD9 & Caspase recruitment domain family, member 9 & -2.75 & $1.8 \mathrm{E}-02$ \\
\hline NM_0I43|2.3 & VSIG2 & V-set and immunoglobulin domain containing 2 & -2.81 & $2.5 \mathrm{E}-03$ \\
\hline NM_020384.2 & CLDN2 & Claudin 2 & -3.03 & $2.5 \mathrm{E}-02$ \\
\hline NM_020299.3 & AKRIBIO & Aldo-keto reductase family I, member BIO & -3.20 & I.7E-02 \\
\hline NM_007193.3 & ANXAIO & Annexin AlO & -3.69 & 4.IE-03 \\
\hline NM_00107I.I & TYMS & Thymidylate synthase & -3.82 & I.IE-03 \\
\hline \multicolumn{3}{|l|}{ Induced } & \multicolumn{2}{|c|}{ Vorinostat } \\
\hline NM_002305.2 & LGALSI & Lectin, galactoside-binding, soluble, I & 5.07 & $1.6 \mathrm{E}-03$ \\
\hline NM_003088.2 & FSCNI & Fascin homolog I, actin-bundling protein & 4.61 & $2.3 \mathrm{E}-04$ \\
\hline NM_004223.3 & UBE2L6 & Ubiquitin-conjugating enzyme E2L 6 & 4.47 & $1.2 \mathrm{E}-02$ \\
\hline NM_006262.3 & PRPH & Peripherin & 4.39 & $5.9 \mathrm{E}-03$ \\
\hline NM_I82908.3 & DHRS2 & Dehydrogenase/reductase member 2 & 4.21 & I.IE-04 \\
\hline NM_006086.2 & TUBB3 & Tubulin, beta 3 & 4.08 & $1.6 \mathrm{E}-03$ \\
\hline NM_002084.2 & GPX3 & Glutathione peroxidase 3 & 3.98 & $2.0 \mathrm{E}-03$ \\
\hline NM_0I7707.2 & DDEFLI & Development and differentiation enhancing factor-like I & 3.74 & $7.9 \mathrm{E}-03$ \\
\hline NM_001928.2 & CFD & Complement factor $D$ & 3.72 & $1.5 \mathrm{E}-02$ \\
\hline NM_003078.3 & SMARCD3 & $\begin{array}{l}\text { SWI/SNF related, matrix associated, actin dependent regulator of chromatin, } \\
\text { subfamily d, member } 3\end{array}$ & 3.67 & $2.0 \mathrm{E}-02$ \\
\hline NM_003283.3 & TNNTI & Troponin T type I & 3.67 & $1.5 \mathrm{E}-03$ \\
\hline NM_006117.2 & $\mathrm{PECl}$ & Peroxisomal D3, D2-enoyl-CoA isomerase & 3.62 & $3.5 \mathrm{E}-03$ \\
\hline NM_I780I2.3 & TUBB2B & Tubulin, beta $2 \mathrm{~B}$ & 3.59 & 7.IE-04 \\
\hline NM_0I5896.2 & ZMYNDIO & Zinc finger, MYND-type containing 10 & 3.57 & $8.8 \mathrm{E}-03$ \\
\hline NM_005319.3 & HISTIHIC & Histone I, HIc & 3.50 & 7.7E-03 \\
\hline \multicolumn{5}{|l|}{ Repressed } \\
\hline NM_001031733.I & CALML4 & Calmodulin-like 4 & -2.43 & $5.0 \mathrm{E}-03$ \\
\hline NM_005752.2 & CLEC3A & C-type lectin domain family 3 , member $A$ & -2.45 & 7.5E-04 \\
\hline NM_005375.2 & MYB & V-myb myeloblastosis viral oncogene homolog & -2.56 & $3.5 \mathrm{E}-03$ \\
\hline NM_02037I.2 & AVEN & Apoptosis, caspase activation inhibitor & -2.60 & $7.8 \mathrm{E}-03$ \\
\hline NM_0I43I 2.3 & VSIG2 & V-set and immunoglobulin domain containing 2 & -2.62 & 3.5E-04 \\
\hline NM_005II7.2 & FGFI9 & Fibroblast growth factor 19 & -2.64 & $9.3 \mathrm{E}-03$ \\
\hline NM_007I67.2 & ZMYM6 & Zinc finger, MYM-type 6 & -2.67 & $1.6 \mathrm{E}-02$ \\
\hline NM_004688.I & NMI & $\mathrm{N}$-myc (and STAT) interactor & -2.69 & $3.9 \mathrm{E}-04$ \\
\hline
\end{tabular}


Table 2: Differentially expressed genes (>2 Fold) in response to HDACi in HT29 colon cancer cells. (Continued)

\begin{tabular}{|c|c|c|c|c|}
\hline NM_0528|3.2 & CARD9 & Caspase recruitment domain family, member 9 & -2.70 & $2.8 \mathrm{E}-04$ \\
\hline NM_0809II.I & UNG & Uracil-DNA glycosylase & -2.79 & $1.6 \mathrm{E}-02$ \\
\hline NM_018689.I & KIAAII 99 & KIAAII 99 & -2.95 & $3.2 \mathrm{E}-04$ \\
\hline NM_020384.2 & CLDN2 & Claudin 2 & -3.06 & $2.3 \mathrm{E}-02$ \\
\hline NM_020299.3 & AKRIBIO & Aldo-keto reductase family I, member BIO & -3.07 & $2.8 \mathrm{E}-05$ \\
\hline NM_007193.3 & ANXAIO & Annexin AlO & -3.49 & I.3E-02 \\
\hline NM_00107I.I & TYMS & Thymidylate synthase & -3.59 & $8.3 \mathrm{E}-03$ \\
\hline NM_001031733.1 & CALML4 & Calmodulin-like 4 & -2.43 & $5.0 \mathrm{E}-03$ \\
\hline
\end{tabular}

tion (up- or downregulation) and cell-line specific modulation between the qPCR and microarray analyses. THBS1, AVEN and AURKB demonstrated significant cell-line specific changes in expression at $24 \mathrm{~h}$ as observed in the microarray analyses (Figure 6B-D). HIST1H1C was initially identified as consistently upregulated by the microarray analysis, but subsequent qPCR analysis indicated this gene to be consistently downregulated with either HDACi in both cell lines (Figure 6E). QPCR validation of our core panel of 11 genes also demonstrated consistent modulation at $24 \mathrm{~h}$ with the microarray analysis. In addition, these 11 genes also demonstrated time-dependent changes in expression at 6 and/or $12 \mathrm{~h}$ post HDACi treatment (Figure 7 and 8). However, in several instances, the fold-changes obtained by qPCR were significantly higher for several genes than those obtained in the microarray analyses, particularly for the more heavily regulated genes as previously reported [40]. For example, DHRS2 was induced by $\sim 5$-fold in both cell lines following HDACi treatment in the microarray analysis. Subsequent qPCR analysis determined the fold-increase in DHRS2 transcripts to be in the order of 36-97-fold in HT29 cells and 226-445-fold in the HCT116 cells (Figure 7). Similarly, thymidylate synthase (TYMS) was down-regulated by HDACi in both cell lines 2.7 - 3.8-fold in the microarray analysis, whereas qPCR determined that HDACi treatment induced a >30-fold downregulation of TYMS $24 \mathrm{~h}$ post-treatment in both cell lines (Figure 8).

\section{Discussion}

In an effort to characterize the response of colon cancer cells to HDACi, we analyzed the gene expression profile of two colon cancer cell lines following treatment with two HDACi, vorinostat and LBH589. Both HDACi resulted in significant inhibition of tumor cell proliferation, an accumulation of acetylated histones and the onset of apoptotic cell death. However, LBH589 exerted antiproliferative effects at significantly lower concentrations than vorinostat, consistent with previous reports utilizing these HDACi $[25,34,41]$. Specifically, the $\mathrm{IC}_{50}$ for LBH589 was in the single digit nanomolar range while vorinostat required concentrations in excess of $1 \mu \mathrm{M}$. The concentrations at which HDACi induce their antiproliferative effects is of importance particularly in the context of clinically achievable serum concentrations and the extrapolation of in vitro observations to clinical settings. Pharmacokinetic data from clinical trials following a twice-daily dose of vorinostat determined that the half-life was in the range of 1 - $3.5 \mathrm{~h}$ and maximal serum concentrations did not peak over $2 \mu \mathrm{M}$ and rapidly diminished $[27,42,43]$. Of note, the half-life of LBH589 was determined to be in the order of 10-14 $\mathrm{h}$ and serum concentrations of $400-700 \mathrm{nM}$ are achievable at doses which are well tolerated [28]. Therefore, the concentration of LBH589 required to achieve $50 \%$ growth inhibition in our colon cancer cells was well within clinically achievable concentrations whereas the concentration of vorinostat was within, but approaching the upper limit of reported serum concentration ranges.

The cDNA microarray analysis demonstrated that in each cell line that the gene expression profile was significantly altered after a $24 \mathrm{~h}$ exposure to either HDAC inhibitor, vorinostat $(2 \mu \mathrm{M})$ or LBH589 $(50 \mathrm{nM})$. Considering the mechanism of action of HDACi including histone acetylation-induced chromatin remodeling and the acetylation of non-histone proteins including transcription factors, it is intriguing that only $5-7 \%$ of genes in the colon cancer cell lines analyzed were modulated by HDACi treatment. However, our results are consistent with other microarray profiling experiments which reported as few as $2 \%$ and as high as $10 \%$ modulated by HDACi. These reports and the data presented herein would indicate that HDACi do not induce global gene expression changes and may instead target specific sets of genes. An important observation in this study was that vorinostat and LBH589 induced very similar transcriptional profiles within each cell line. As both of these agents are hydroxamate-class HDACi, this observation is somewhat expected. Additional studies have identified very similar transcriptional changes produced by the two hydroxamic-acid based HDACi, TSA and vorinostat, while also demonstrating a different gene expression profile obtained with the benzamide class HDACi MS-275 [14].

The analysis of our data demonstrates that HDACi induce significant cell-line specific effects on genes involved in the regulation of a number of critical tumor processes including angiogenesis, mitosis, DNA replication, recombination and repair and apoptosis. More specifically, the potent anti-angiogenic matrix glycoprotein throm- 

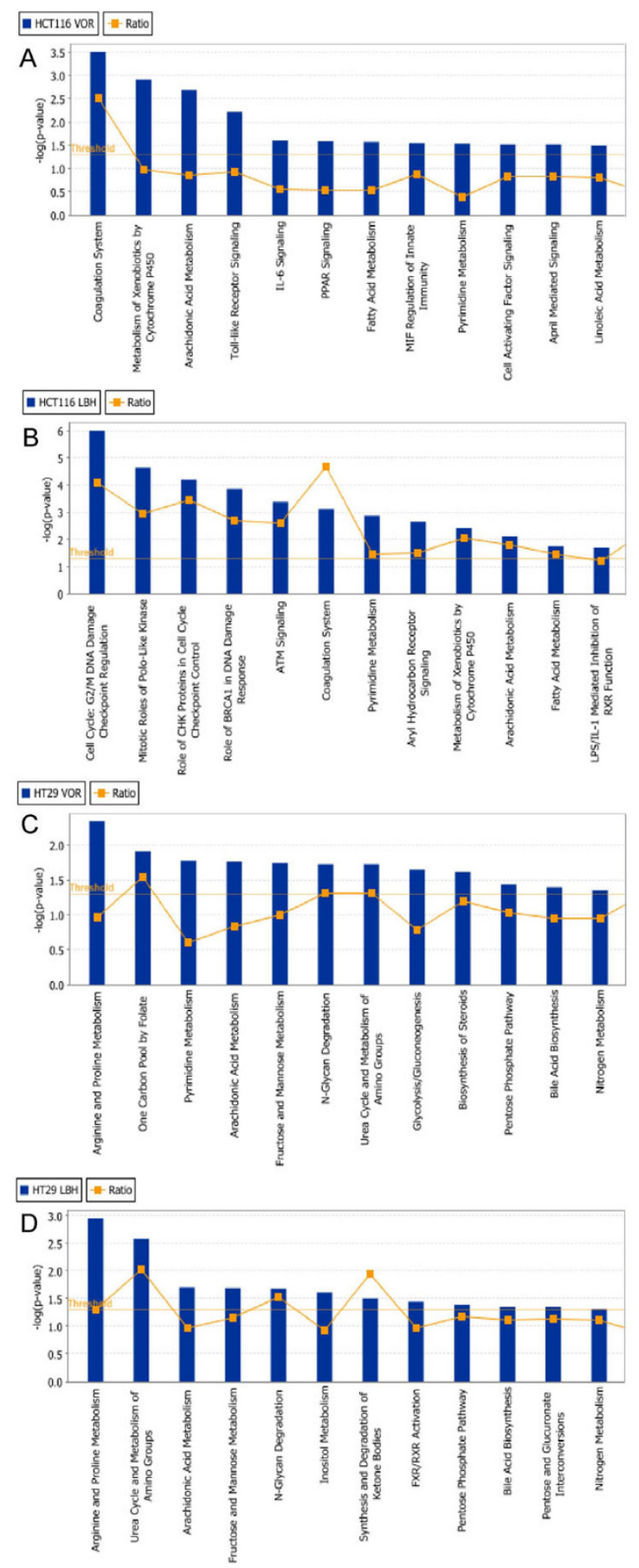

\section{Figure 5}

Top 12 canonical pathways that were significantly modulated by HDACi as identified by Ingenuity ${ }^{\circledR}$ Pathway Analysis (IPA). HCTI 16 colon cancer cells treated for $24 \mathrm{~h}$ with (A) $2 \mu \mathrm{M}$ vorinostat (Vor) or (B) $50 \mathrm{nM}$ LBH589 (LBH); HT29 colon cancer cells treated for $24 \mathrm{~h}$ with (C) $2 \mu$ M vorinostat (Vor) or (D) $50 \mathrm{nM}$ LBH589 (LBH). 2289 of the 3043 differentially expressed genes (DEGs) in the HCTII 6 and 1679 of the 2232 DEGs in the HT29 cancer cell lines mapped to defined genetic networks in IPA. Fisher's exact test was used to calculate a $p$-value determining the probability that the association between the genes in the dataset and the canonical pathway is explained by chance alone. A ratio of the number of genes from the dataset that map to the pathway divided by the total number of molecules in a given pathway that meet the cut criteria, divided by the total number of molecules that make up that pathway is displayed. 
Table 3: Summary of changes in gene expression for the core set of HDAC inhibitor regulated genes

\begin{tabular}{|c|c|c|c|c|c|c|}
\hline \multirow{3}{*}{$\begin{array}{l}\text { Accession \# } \\
\text { Induced }\end{array}$} & \multirow{3}{*}{ Gene Symbol } & \multirow{3}{*}{ Gene Name } & \multicolumn{2}{|c|}{ HCTII6 } & \multicolumn{2}{|c|}{ HT29 } \\
\hline & & & \multicolumn{2}{|c|}{ Fold Change* } & \multicolumn{2}{|c|}{ Fold Change* } \\
\hline & & & LBH589 & VOR & LBH589 & VOR \\
\hline NM_182908.3 & DHRS2 & Dehydrogenase/reductase member 2 & 4.78 & 4.05 & 4.37 & 4.21 \\
\hline NM_183376.I & ARRDC4 & Arrestin domain containing 4 & 4.15 & 3.35 & 2.21 & 2.14 \\
\hline NM_138720.I & HISTIH2BD & Histone $\mathrm{I}, \mathrm{H} 2 \mathrm{bd}$ & 3.35 & 2.53 & 3.44 & 3.33 \\
\hline NM_005952.2 & MTIX & Metallothionein IX & 2.87 & 2.37 & 3.66 & 3.31 \\
\hline NM_005950.I & MTIG & Metallothionein IG & 2.78 & 2.08 & 3.30 & 3.00 \\
\hline NM_0I5I49.2 & RGLI & Tal guanine nucleotide dissociation stimulator-like I & 2.52 & 1.56 & 3.12 & 3.03 \\
\hline \multicolumn{7}{|l|}{ Repressed } \\
\hline NM_00I07I.I & TYMS & Thymidylate synthase & -3.88 & -2.74 & -3.82 & -3.59 \\
\hline NM_|45810.1 & CDCA7 & Cell division cycle associated 7 & -3.06 & -2.08 & -2.59 & -2.42 \\
\hline NM_0809II.I & UNG & Uracil-DNA glycosylase & -2.54 & -1.55 & -2.58 & -2.79 \\
\hline NM_003998.2 & NFkBI & $\begin{array}{l}\text { Nuclear factor of kappa light polypeptide gene enhancer in B-cells I } \\
\text { (pI05) }\end{array}$ & -2.55 & -2.04 & -1.65 & -1.8 \\
\hline NM_001025242.I & IRAKI & Interleukin-I receptor-associated kinase I & -1.97 & -1.65 & -2.15 & -2.08 \\
\hline
\end{tabular}

bospondin-1 (THBS1), was significantly upregulated 14fold in HCT116 cells at $24 \mathrm{~h}$ (Table 1). HT29 cells however, showed no modulation until $24 \mathrm{~h}$ post-treatment where only a modest increase of 2 -fold was observed by qPCR. HDACi are reported to be potent inhibitors of tumor angiogenesis and induction of THBS1 has previously been reported following HDAC inhibition [44]. Similarly, in HCT116 the most heavily upregulated gene following treatment with either vorinostat or LBH589 was connective tissue growth factor (CTGF; Table 1). CTGF is a multifunctional secreted matricellular protein associated with fibrotic disorders, angiogenic regulation, and possibly tumor development [45]. Human tumors overexpressing CTGF demonstrated reduced microvessel density indicative of potential antiangiogenic properties, and ovarian tumors overexpressing CTGF demonstrated enhanced tumor cell invasion [46]. In HT29 cells, fibroblast growth factor 19 (FGF19) was significantly downregulated by both HDACi (Table 2). FGF19 binds to FGF receptor 4 and has been shown to mediate cell cycle progression, angiogenesis and promote tumor growth through the beta-catenin pathway. Knockdown of FGF19 in colon cancer cells decreased tumor growth in vitro and in vivo [47]. It is possible that the antiangiogenic and antitumor action of HDACi are mediated, in part, through modulation of key angiogenic regulators such as these and would indicate that HDACi may potentiate the therapeutic efficacy when used in combination with inhibitors of tumor angiogenesis.

In HT29 cells, microarray analysis identified that both HDACi induce a potent downregulation of the anti-apoptotic caspase inhibitor protein AVEN. qPCR confirmed that AVEN is significantly downregulated in HT29 cells by vorinostat and LBH589 $>5$-fold at $24 \mathrm{~h}$ and only modestly regulated in HCT116 cells <2-fold at $24 \mathrm{~h}$. AVEN is reported to inhibit caspase activation through inhibition of APAF-1 self-association [48]. The downregulation of AVEN would suggest that HDACi-induced apoptosis in the HT29 cells may be regulated in part via the mitochondria, supporting the mechanism of oxidative stress injury as previously reported [18].

We also observed significant cell-line-specific alterations in genes involved in mitosis. Aurora kinase B was identified as downregulated by both vorinostat and LBH589 in HCT116 cells. The Aurora kinase family are critical regulators of mitotic cell division having roles in centrosome function, mitotic spindle formation, chromosome segregation and cytokinesis [49]. Overexpression of Aurora kinases A and B have been linked to genetic instability and are frequently overexpressed in solid tumors such as colorectal cancer [50,51] and inhibition of aurora kinases has become an attractive therapeutic strategy with multiple inhibitors in clinical development. Of note, recent studies have reported that LBH589 induces the degradation of aurora kinase A and B in renal and non-small cell lung cancer cells resulting in G2/M arrest and apoptosis $[52,53]$. Interestingly, we observed downregulation of aurora kinase $\mathrm{B}$ with HDACi treatment only in the HCT116 cells where a potent G2/M arrest and significant apoptosis was observed (Table 1, Figure 5B).

Approximately $18 \%$ of the DEGs identified after HDACi treatment were modulated in a similar manner in both cell lines. This core set of genes encompass genes involved in cell cycle, nucleotide metabolism, nucleosome assembly and apoptosis. We identified a panel of 11 genes, 6 upand 5 downregulated by both HDACi in both cell lines. Previously, Glaser et al. identified a core set of 13 genes regulated by three HDACis in bladder and breast cancer carcinoma cell line models. Upon comparison, one upreg- 
A

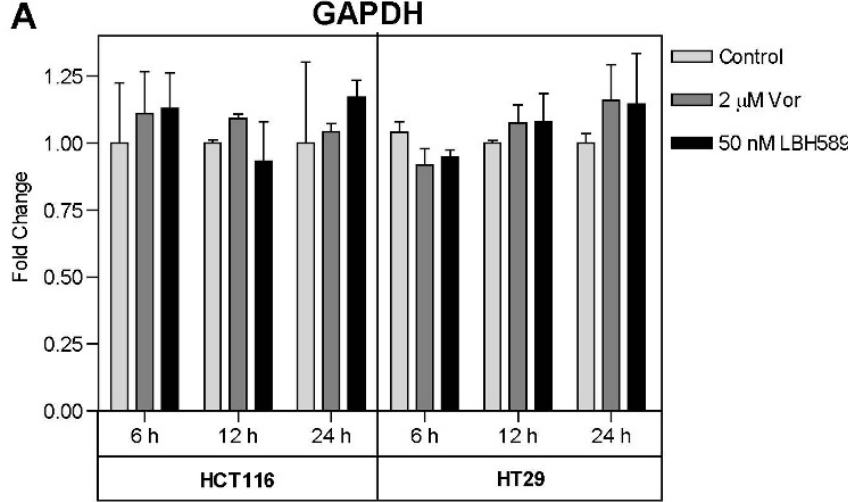

B

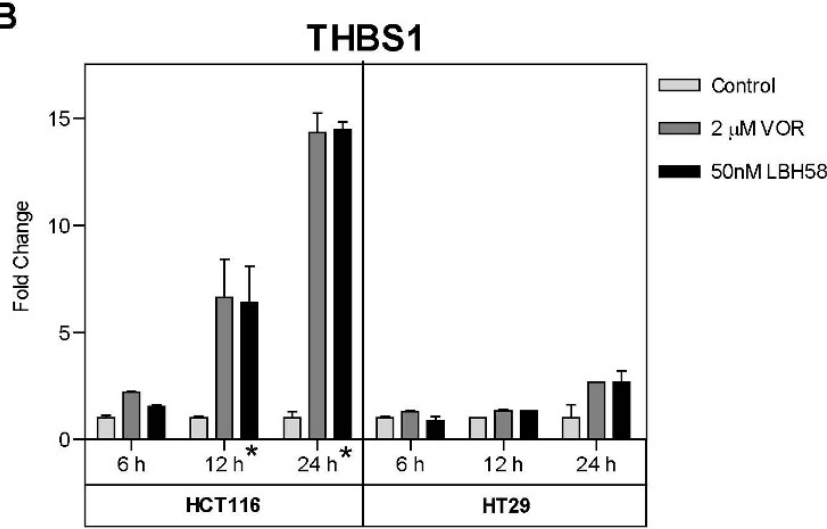

D

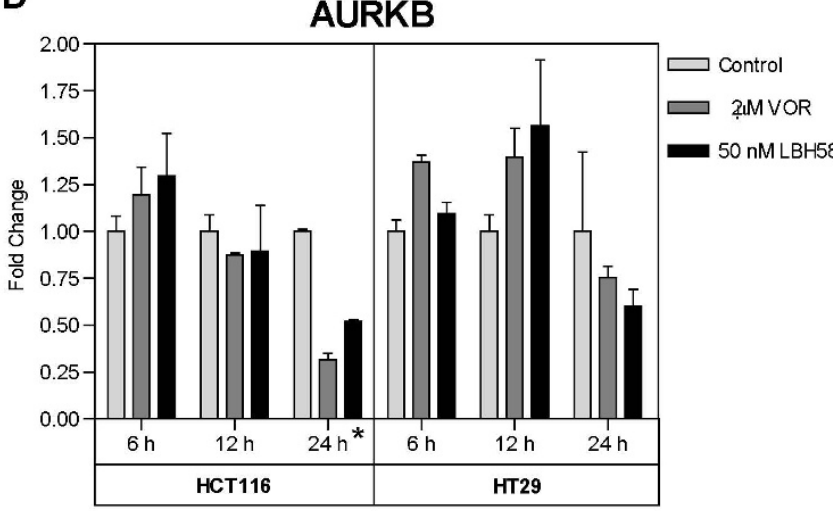

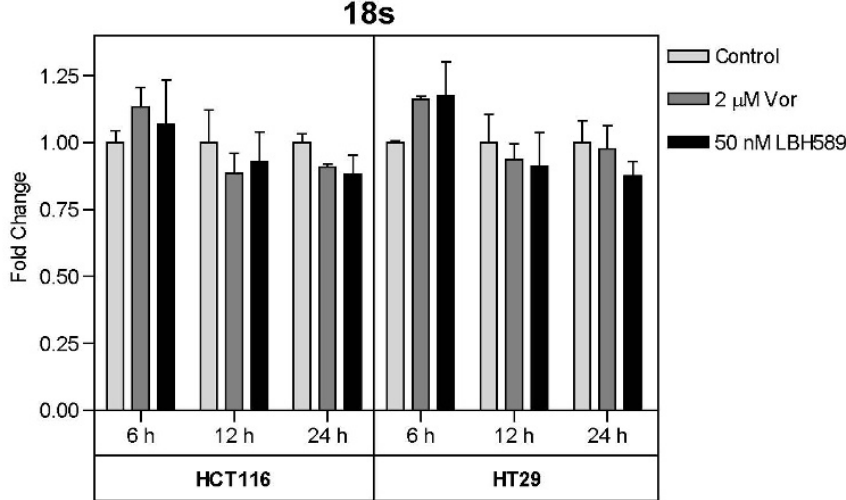

C AVEN

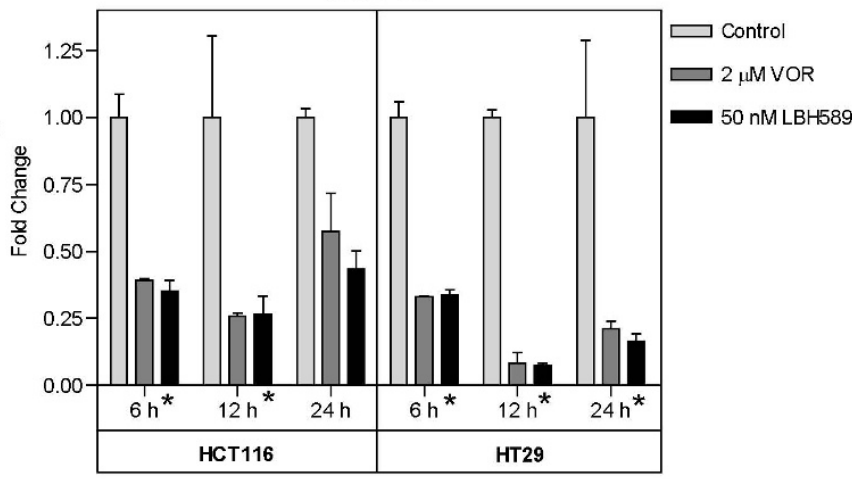

E

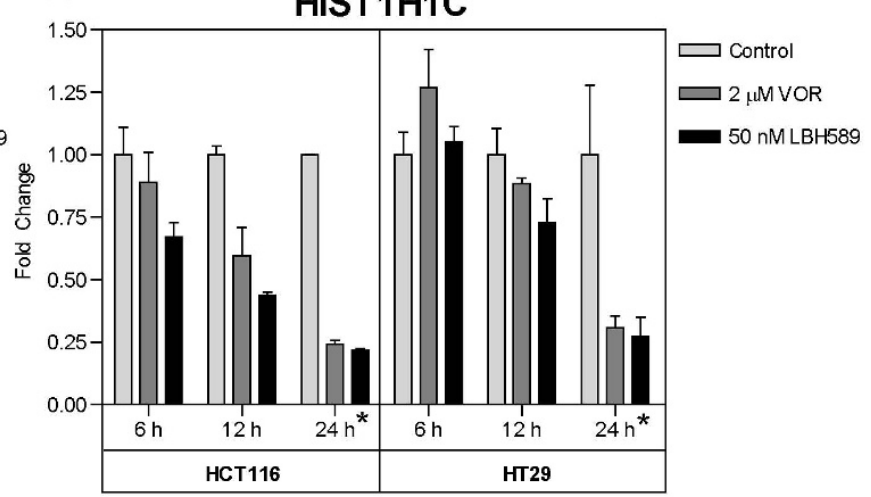

Figure 6

qPCR validation of house-keeping and cell-line specific HDACi-induced gene expression changes. HCTII6 and HT29 cells were treated with $2 \mu \mathrm{M}$ vorinostat or $50 \mathrm{nM} \mathrm{LBH589}$ for 6,12 and $24 \mathrm{~h}$. Total RNA was extracted and qPCR analysis was performed as described in the 'materials and methods' using the primer sets given in Table 4. Histogram bars represent the mean \pm SD for two independent RNA isolations analyzed in triplicate. (A) Verification of unaffected I8s and GAPDH expression with HDACi treatment. GAPDH was normalized to $18 \mathrm{~s}$ and $18 \mathrm{~s}$ was normalized to GAPDH. $\mathrm{qPCR}$ validation of the induction of (B) THBS-I, (C) AVEN (D) AURKB (E) HISTIHIC. All genes were normalized to GAPDH, $*$ denotes a $p$ value $<0.05$ for both HDACi treatment groups when compared to respective time-matched control. 

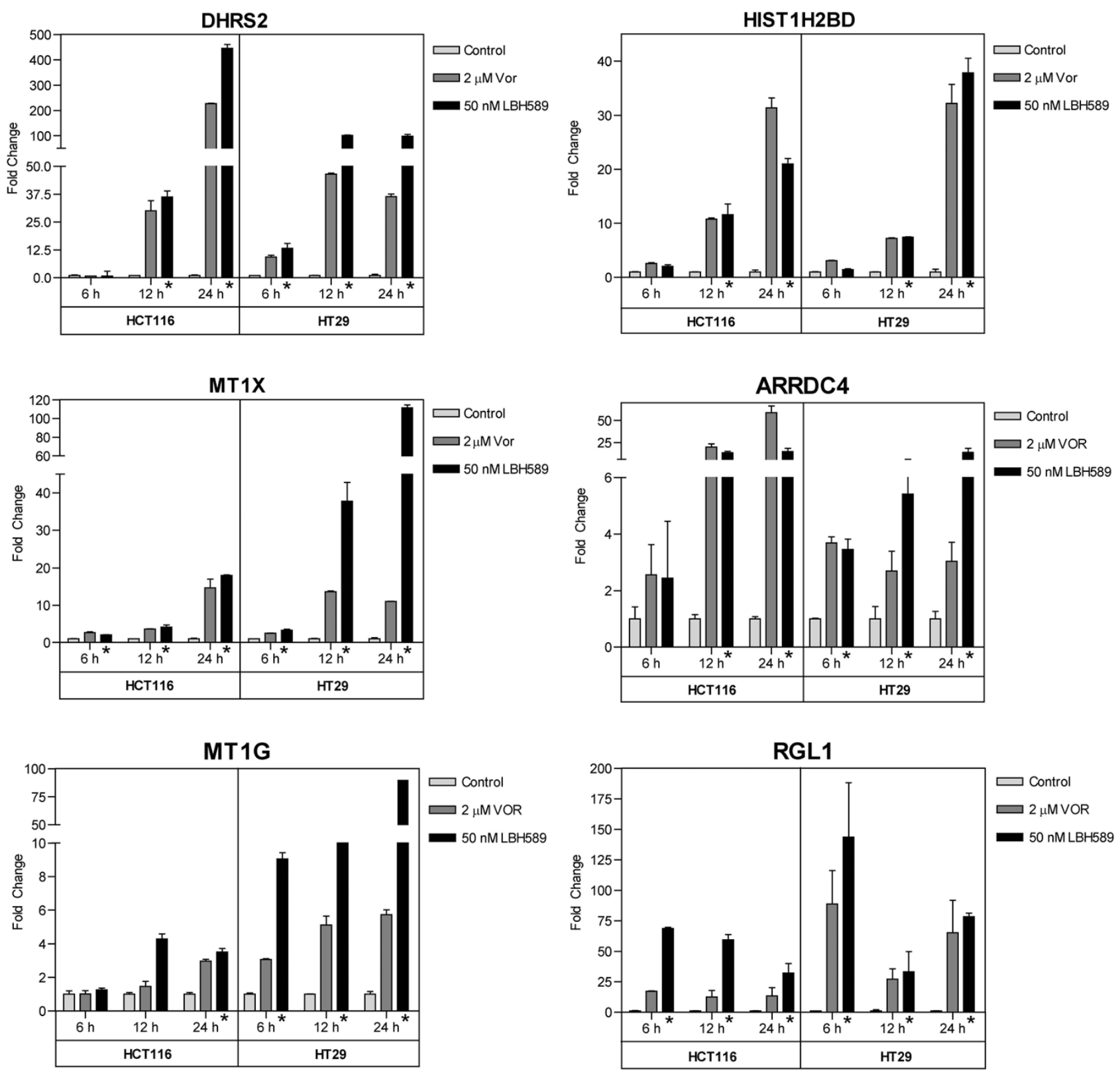

Figure 7

qPCR time-dependent validation of core HDACi-induced gene expression changes in HCT I 16 and HT29 cells. HCTI 16 and HT29 cells were treated with $2 \mu$ M vorinostat (Vor) or 50 nM LBH589 for 6, I 2 and 24 h. Total RNA was extracted, reverse transcribed and qPCR analysis was performed as described in the 'materials and methods' using the primer sets given in Table 4. Histogram bars represent the mean \pm SD for two independent RNA isolations analyzed in triplicate. All genes were normalized to GAPDH, * denotes $p$-value $<0.05$ for both HDACi treatment groups when compared to respective time-matched control.

ulated gene (histone $\mathrm{H} 2 \mathrm{~B}$ ) and one down-regulated gene (thymidylate synthase) are consistent between our core gene set and those reported by Glaser et al. [14]. One of the primary reasons for this is that out core gene set was defined solely from colon cancer cells which are physiologically distinct from both bladder and breast cancers and may employ different mechanisms of gene expression regulation. An additional study analyzed the effects of HDACi in renal cancer cells and identified consistent directional modulation of short-chain alcohol dehydrogenase, aldo-keto reductase and fibroblast growth factor gene families [54]. 

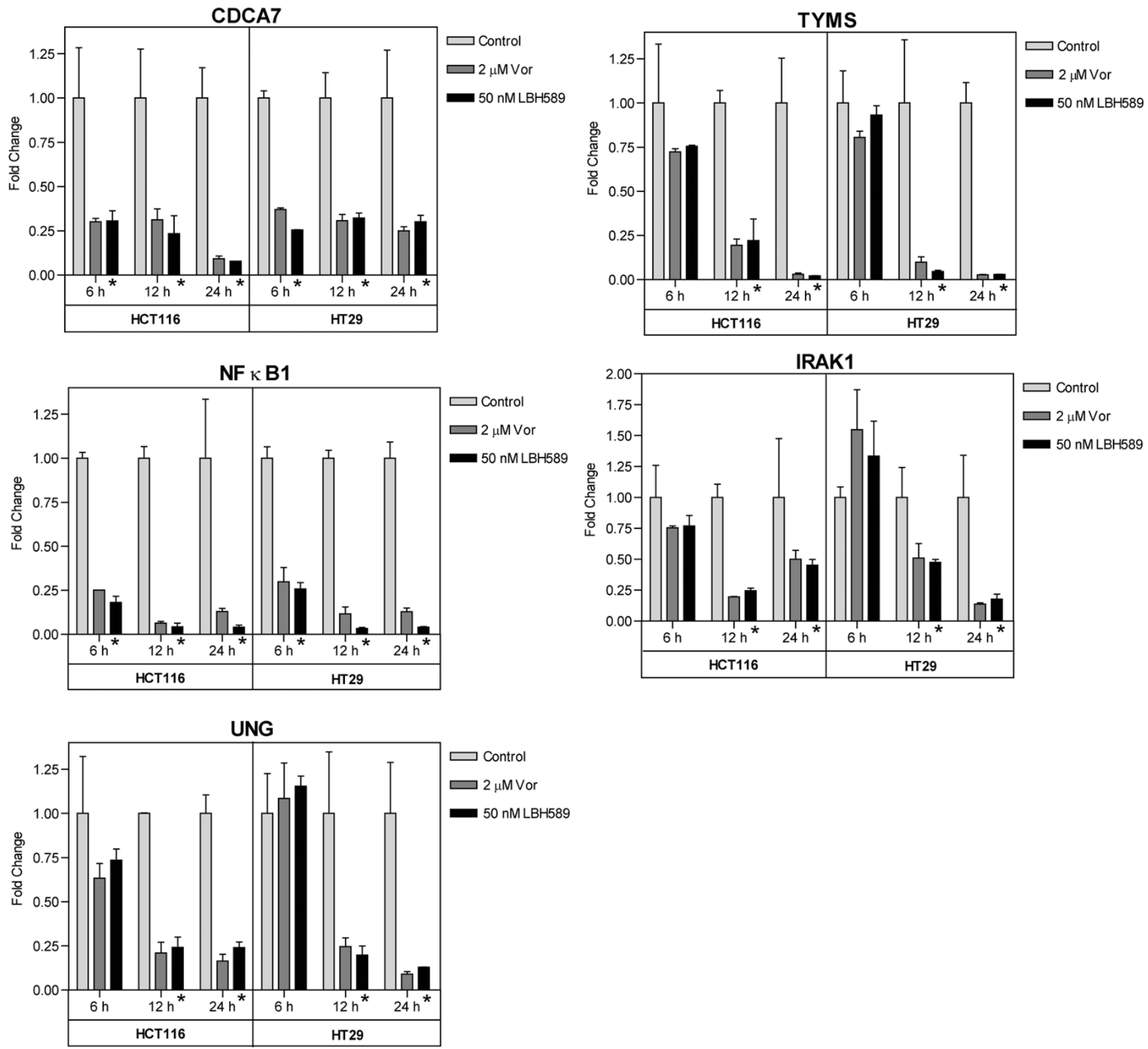

Figure 8

qPCR time-dependent validation of core HDACi-repressed gene expression changes in HCTII6 and HT29 cells. HCTII 6 and HT29 cells were treated with $2 \mu$ M vorinostat (Vor) or $50 \mathrm{nM} \mathrm{LBH589} \mathrm{for} \mathrm{6,} 12$ and $24 \mathrm{~h}$. Total RNA was extracted, reverse transcribed and QPCR analysis was performed as described in the 'materials and methods' using the primer sets given in Table 4. Histogram bars represent the mean \pm SD for two independent RNA isolations analyzed in triplicate. All genes were normalized to GAPDH, * denotes $p$-value $<0.05$ for both HDACi treatment groups when compared to respective time-matched control.

Two genes within our core set of HDACi-modulated genes are directly involved in nucleotide metabolism and DNA repair. Downregulation of both thymidylate synthase (TYMS) and UNG was observed in both cell lines following treatment with either HDACi. Thymidylate synthase is essential for the de novo synthesis of thymidylate, an essential precursor required for DNA replication and repair. UNG is the gene encoding uracil-DNA glycosylase, a base excision repair protein involved in uracil excision from DNA. Both these enzymes are reported to mediate response to the antimetabolite class of chemotherapeutic agents including inhibitors of TS such as 5-fluorouracil 
Table 4: qPCR Primer Sequences

\begin{tabular}{|c|c|c|c|c|}
\hline & & & & \\
\hline Name & Accession \# & Strand & Primer Sequence & Size (bp) \\
\hline \multirow[t]{2}{*}{ I8s rRNA } & NR_003286.I & $\mathrm{F}$ & CGCCGCTAGAGGTGAAATTC & 62 \\
\hline & & $\mathrm{R}$ & TTGGCAAATGCTTTCGCTC & \\
\hline \multirow[t]{2}{*}{ ARRDC4 } & NM_I83376.2 & $\mathrm{F}$ & CCGGCCGGTGAAGGCATCAT & 140 \\
\hline & & $\mathrm{R}$ & TCCAACACTGCCCGCACACA & \\
\hline \multirow[t]{2}{*}{ AURKB } & NM_0042I7.2 & $\mathrm{F}$ & GACCTAAAGTTCCCCGCTTC & 165 \\
\hline & & R & GACAGATTGAAGGGCAGAGG & \\
\hline \multirow[t]{2}{*}{ AVEN } & NM_02037I.2 & $\mathrm{F}$ & TGCTCACAGCAGTAAATGCC & 155 \\
\hline & & $\mathrm{R}$ & TGCAAGGAAGGAGGCTAGAA & \\
\hline \multirow[t]{2}{*}{ CDCA7 } & NM_031942.4 & $\mathrm{F}$ & CATGGAAACCTCGTCATCCT & 95 \\
\hline & & $\mathrm{R}$ & TACAGCCTTCCCGAACTGAC & \\
\hline \multirow[t]{2}{*}{ DHRS2 } & NM_I82908.4 & $\mathrm{F}$ & GTCCTTCCTGTGCTCTCCAG & 169 \\
\hline & & $\mathrm{R}$ & AGACTCTGCCTCCAGATCCA & \\
\hline \multirow[t]{2}{*}{ GAPDH } & NM_002046.3 & $\mathrm{F}$ & ATGGGGAAGGTGAAGGTCG & 107 \\
\hline & & R & GGGTCATTGATGGCAACAATATC & \\
\hline \multirow[t]{2}{*}{ HISTIHIC } & NM_005319.3 & $\mathrm{F}$ & ACACCGAAGAAAGCGAAGAA & 116 \\
\hline & & $\mathrm{R}$ & AGCCTTAGCAGCACTTTTGG & \\
\hline \multirow[t]{2}{*}{ HISTIH2BD } & NM_I38729.I & $\mathrm{F}$ & AAGGCCGTCACCAAGTACAC & 136 \\
\hline & & $\mathrm{R}$ & TTTCAGGCAGATGAGACTTCC & \\
\hline \multirow[t]{2}{*}{ IRAKI } & NM_000I569.3 & $\mathrm{F}$ & GCTGGCCCTGTACGAGGAT & 129 \\
\hline & & $\mathrm{R}$ & ACACATCAGCTCTGAAATTCATCAC & \\
\hline \multirow[t]{2}{*}{ MTIG } & NM_005950.I & $\mathrm{F}$ & ССССАACTGCTCCTGTGCCG & 202 \\
\hline & & R & GGGAGCAGGGCTGTCCCGA & \\
\hline \multirow[t]{2}{*}{ MTIX } & NM_005952.3 & $\mathrm{F}$ & GCAAATGCAAAGAGTGCAAA & 146 \\
\hline & & $\mathrm{R}$ & ACAGCTGTCCTGGCATCAG & \\
\hline \multirow[t]{2}{*}{$\mathrm{NF}_{\mathrm{K}} \mathrm{BI}$} & NM_003998.2 & $\mathrm{F}$ & CACGAATGACAGAGGCGTGTA & 130 \\
\hline & & $\mathrm{R}$ & TGGCGGATTAGCTCTTTTTCC & \\
\hline \multirow[t]{2}{*}{ RGLI } & NM_0I5I49.3 & $\mathrm{F}$ & GCCGTCCCAAGGGACCGAATG & 166 \\
\hline & & $\mathrm{R}$ & GCCGCCTCTGGGTACGCTTC & \\
\hline \multirow[t]{2}{*}{ THBSI } & NM_003246.2 & $\mathrm{F}$ & CACGCTGCAGGACAGCAT & 69 \\
\hline & & $\mathrm{R}$ & GGCCGCCTCAGCTCATT & \\
\hline \multirow[t]{2}{*}{ TYMS } & NM_00I07I.2 & $\mathrm{F}$ & GGAGGAGTTGCTGTGGTTTATCAAG & 108 \\
\hline & & $\mathrm{R}$ & AGGCTGTCCAAAAAGTCTCGGG & \\
\hline \multirow[t]{2}{*}{ UNG } & NM_003362.2 & $\mathrm{F}$ & TTATGGTGAAACAGGGGAGA & 176 \\
\hline & & $\mathrm{R}$ & AGTGGAACTGGCAGAGACTG & \\
\hline
\end{tabular}

$[55,56]$. A number of other studies have confirmed that downregulation of TS mRNA and protein is a common event in response to HDACi treatment $[14,25,57]$. We recently confirmed that downregulation of TS was a common event in an extended panel of colon cell lines and was driven primarily through a transcriptional mechanism in response to HDAC inhibition. This interaction resulted in synergistic antiproliferative effects between HDACi and 5-FU in colon cancer cells [25] supporting the concept that HDACi-mediated alterations in known drug targets may provide opportunity for new therapeutic combinations.

Short-chain alcohol dehydrogenase family member 2 (DHRS2) was identified as the most heavily induced gene by HDACi in our core set of genes. DHRS2 was originally identified following its upregulation by treatment with butyrate and was later confirmed to be involved in the differentiation of monocytes to dendritic cells $[58,59]$.
HDACi treatment is reported to induce cellular differentiation and induction of pro-differentiation genes such as DHRS2 is a plausible mechanism [60].

MT1X and MT1G were both heavily induced in both cell lines by HDACi treatment. These genes encode two highly inducible ubiquitous proteins belonging to a family of cysteine-rich metallothionein proteins. Metallothioneins can bind to both physiological and xenobiotic heavy metals [61]. Previous studies have identified regulation of other metallothionein family members in response to HDACi [14]. MT1G is reported to be a tumor suppressor gene and is frequently epigenetically silenced in a number of human malignancies $[62,63]$. Although the mechanism that results in the induction of metallothionein proteins is unknown, both the MT1X and MT1G genes map to chromosome 16q13 and it is likely that HDACi-mediated events in this region such as chromatin relaxation result in the increased transcription of both of these genes. 
NF- $\kappa \mathrm{B}$ regulates the expression of a significant number of genes involved in immune response, angiogenesis, cell adhesion, proliferation, differentiation, and apoptosis $[64,65]$. The NFKB1 gene encodes the predominant p50/ p105 form and represents one of the core genes significantly downregulated by HDACi treatment in this study. As such, many different types of human tumors have dysregulated NF- $\kappa \mathrm{B}$, primarily via constitutive activation that mediates continued cell proliferation and averts the onset of apoptosis [66]. Downregulation of NF- $\kappa B$ is a likely mechanism by which HDACi induce aspects of their apoptotic effects in colon cancer cells. We also identified the IL-1 receptor associated kinase (IRAK1) as consistently downregulated by HDACi in our core set of genes. IRAK1 encodes the interleukin-1 receptor-associated kinase 1 which is reported to be partially responsible for IL1induced upregulation of NF- $\mathrm{KB}$ [67] and was one of $\sim 100$ genes identified as consistently upregulated in a microarray meta-comparison of genes upregulated in solid tumors of epithelial origin [68].

Our core set of genes includes the histone family member HIST1H2BD which encodes the histone H2B protein and was $>3$-fold induced by HDACi treatment. HIST1H2BD has previously been reported to be induced by HDACi treatment [14]. While the mechanism of induction of this gene is unknown, it is located within the large histone gene cluster on chromosome 6p22-p21.3 and it is likely that the HDACi-induced alterations in this region, possibly through chromatin relaxation allowing transcriptional machinery access, results in this induction.

We have analyzed the gene expression profiles of two of the most clinically advanced hydroxamate class HDACi, vorinostat and LBH589, in two colon cancer cell line models. We identified significant overlap in differentially expressed gene profiles for vorinostat and LBH589 within each cell line indicating similar mechanism of action for these HDACi. Interestingly, we also identified a strong cell-line dependence of gene expression changes induced by these HDACi with only $18 \%$ commonality in HDACiinduced DEGs. Within this gene expression overlap, we identified a core set of 6 up- and 5 downregulated genes that are regulated by both of HDACi in both cell lines. Defining a core set of genes that represent markers of HDAC inhibition is an important first step in the identification and validation of clinical markers for evaluating HDACi target inhibition and efficacy. Currently, analysis of histone acetylation from tumor tissue and more frequently from isolated peripheral blood mononuclear cells is used as evidence of HDACi biological activity. However, histone acetylation following HDACi treatment has been shown to be highly reversible and often inconsistent. A panel of HDACi-regulated genes may provide a more sensitive and reliable means to determining the efficacy of HDACi treatment in the clinic. We also identified altera- tions in additional pathways which may enhance the therapeutic potential of both conventional and targeted therapeutics, including genes involved in angiogenesis, nucleotide metabolism and mitosis. As HDACi advance in clinical development, these agents are likely to be incorporated into combination treatment strategies with both conventional and novel chemotherapeutic agents. Therefore, the identification of pathways and drug targets modulated by HDAC inhibition could be critically important in elucidating their disease-specific mechanism of action and assisting in the identification of effective drug combination partners.

\section{Conclusion}

This study identified HDACi-induced alterations in critical genes involved in nucleotide metabolism, angiogenesis, mitosis and cell survival which may represent potential intervention points for novel therapeutic combinations in colon cancer. This information will assist in the identification of novel pathways and targets that are modulated by HDACi, providing much-needed information on HDACi mechanism of action and providing rationale for novel drug combination partners. We identified a core signature of 11 genes which were modulated by both vorinostat and LBH589 in a similar manner in both cell lines. These core genes will assist in the development and validation of a common gene set which may represent a molecular signature of HDAC inhibition in colon cancer.

\section{Abbreviations}

HDAC: histone deacetylase; HDACi: histone deacetylase inhibitor; HAT: histone acetyl transferase; FDR: false discovery rate; CTCL: cutaneous T-cell lymphoma; metallothionein; MT: thymidylate synthase (gene); TYMS: (protein) TS; NFkB: nuclear factor kappa-light-chainenhancer of activated B cells; qPCR: quantitative reversetranscriptase PCR; DEG(s): differentially expressed gene(s).

\section{Competing interests}

HJL has received financial support for consultation and clinical trial support from Novartis and clinical trial support from Merck. The remaining authors of this manuscript have no competing interests to declare.

\section{Authors' contributions}

All authors conceived the experiment design. MJL, WF and PMW performed the cell culture, RNA extraction and quality control prior to microarray analysis. MJL, PMW and WF performed the quantitative RT-PCR. MJL and PMW performed the growth inhibition analysis, Western blotting and flow cytometric analysis. SG supervised all statistical analyses. All authors interpreted the results. The manuscript was drafted by MJL, PMW and WF. All authors approved the final manuscript. 


\section{Acknowledgements}

This research was funded by the V-Foundation-AACR Grant for Translational Research, the Littlefield-ACCR Grant for Metastatic Colon Cancer Research, the Robert E. Burns Memorial and NCl CCSG grant number 5 P30 CA0I4089.

\section{References}

I. Struhl K: Histone acetylation and transcriptional regulatory mechanisms. Genes Dev 1998, I 2(5):599-606.

2. Glaser KB: HDAC inhibitors: clinical update and mechanismbased potential. Biochem Pharmacol 2007, 74(5):659-67l.

3. Bali P, Pranpat M, Bradner J, Balasis M, Fiskus W, Guo F, Rocha K, Kumaraswamy S, Boyapalle S, Atadja P, et al.: Inhibition of histone deacetylase 6 acetylates and disrupts the chaperone function of heat shock protein 90: a novel basis for antileukemia activity of histone deacetylase inhibitors. I Biol Chem 2005, 280(29):26729-26734.

4. Glozak MA, Sengupta N, Zhang $X$, Seto E: Acetylation and deacetylation of non-histone proteins. Gene 2005, 363:15-23.

5. Hubbert C, Guardiola A, Shao R, Kawaguchi Y, Ito A, Nixon A, Yoshida $M$, Wang XF, Yao TP: HDAC6 is a microtubule-associated deacetylase. Nature 2002, 4I7(6887):455-458.

6. Prystowsky MB, Adomako A, Smith RV, Kawachi N, McKimpson W, Atadja P, Chen Q, Schlecht NF, Parish JL, Childs G, et al.: The histone deacetylase inhibitor LBH589 inhibits expression of mitotic genes causing G2/M arrest and cell death in head and neck squamous cell carcinoma cell lines. J Pathol 2009, 2। 8(4):467-77.

7. Stevens FE, Beamish H, Warrener R, Gabrielli B: Histone deacetylase inhibitors induce mitotic slippage. Oncogene 2008, 27(10): 1345-1354.

8. Ishii S, Kurasawa Y, Wong J, Yu-Lee LY: Histone deacetylase 3 localizes to the mitotic spindle and is required for kinetochore-microtubule attachment. Proc Natl Acad Sci USA 2008, I05(I I):4I79-4I84.

9. Marquard L, Gjerdrum LM, Christensen IJ, Jensen PB, Sehested M, Ralfkiaer E: Prognostic significance of the therapeutic targets histone deacetylase I, 2, 6 and acetylated histone $\mathrm{H} 4$ in cutaneous T-cell lymphoma. Histopathology 2008, 53(3):267-277.

10. Abbas A, Gupta S: The role of histone deacetylases in prostate cancer. Epigenetics 2008, 3(6):300-309.

II. Suzuki J, Chen YY, Scott GK, Devries S, Chin K, Benz CC, Waldman FM, Hwang ES: Protein acetylation and histone deacetylase expression associated with malignant breast cancer progression. Clin Cancer Res 2009, I5(9):3 I63-3I7I.

12. Hanigan CL, Van Engeland M, De Bruine AP, Wouters KA, Weijenberg MP, Eshleman JR, Herman JG: An inactivating mutation in HDAC2 leads to dysregulation of apoptosis mediated by APAFI. Gastroenterology 2008, I35(5):1654-1664.

13. Wilson AJ, Byun DS, Nasser S, Murray LB, Ayyanar K, Arango D, Figueroa M, Melnick A, Kao GD, Augenlicht LH, et al.: HDAC4 promotes growth of colon cancer cells via repression of p2I. Mol Biol Cell 2008, 19(10):4062-4075.

14. Glaser KB, Staver M], Waring JF, Stender J, Ulrich RG, Davidsen SK: Gene expression profiling of multiple histone deacetylase (HDAC) inhibitors: defining a common gene set produced by HDAC inhibition in T24 and MDA carcinoma cell lines. Mol Cancer Ther 2003, 2(2): 15।-163.

15. Bolden JE, Peart MJ, Johnstone RW: Anticancer activities of histone deacetylase inhibitors. Nat Rev Drug Discov 2006, 5(9):769-784.

16. Marks P, Rifkind RA, Richon VM, Breslow R, Miller T, Kelly WK: Histone deacetylases and cancer: causes and therapies. Nat Rev Cancer 200I, I (3): 194-202.

17. Drummond DC, Noble CO, Kirpotin DB, Guo Z, Scott GK, Benz CC: Clinical development of histone deacetylase inhibitors as anticancer agents. Annu Rev Pharmacol Toxicol 2005, 45:495-528.

18. Portanova P, Russo T, Pellerito O, Calvaruso G, Giuliano M, Vento R, Tesoriere $G$ : The role of oxidative stress in apoptosis induced by the histone deacetylase inhibitor suberoylanilide hydroxamic acid in human colon adenocarcinoma HT-29 cells. Int J Oncol 2008, 33(2):325-33I.

19. Richon VM, Emiliani S, Verdin E, Webb Y, Breslow R, Rifkind RA, Marks PA: A class of hybrid polar inducers of transformed cell differentiation inhibits histone deacetylases. Proc Natl Acad Sci USA 1998, 95(6):3003-3007.

20. Richon VM, Garcia-Vargas J, Hardwick JS: Development of vorinostat: Current applications and future perspectives for cancer therapy. Cancer Lett 2009, 280(2):20I-210.

21. Atadja P: Development of the pan-DAC inhibitor panobinostat (LBH589): Successes and challenges. Cancer Lett 2009, 280(2):233-4I.

22. American Cancer Society: Cancer Facts \& Figures 2008. 2008 [http://www.cancer.org]. Atlanta: American Cancer Society

23. Douillard JY, Cunningham D, Roth AD, Navarro M, James RD, Karasek P, Jandik P, Iveson T, Carmichael J, Alakl M, et al.: Irinotecan combined with fluorouracil compared with fluorouracil alone as first-line treatment for metastatic colorectal cancer: a multicentre randomised trial. Lancet 2000, 355(9209): 1041-1047.

24. Giacchetti S, Perpoint B, Zidani R, Le Bail N, Faggiuolo R, Focan C, Chollet P, Llory JF, Letourneau Y, Coudert B, et al.: Phase III multicenter randomized trial of oxaliplatin added to chronomodulated fluorouracil-leucovorin as first-line treatment of metastatic colorectal cancer. J Clin Oncol 2000, I 8(I): I36-I47.

25. Fazzone W, Wilson PM, Labonte MJ, Lenz HJ, Ladner RD: Histone deacetylase inhibitors suppress thymidylate synthase gene expression and synergize with the fluoropyrimidines in colon cancer cells. Int $J$ Cancer 2009, I 25(2):463-73.

26. Richon VM, Sandhoff TW, Rifkind RA, Marks PA: Histone deacetylase inhibitor selectively induces p2 IWAFI expression and gene-associated histone acetylation. Proc Natl Acad Sci USA 2000, 97(18): 10014-10019.

27. Kelly WK, Richon VM, O'Connor O, Curley T, MacGregor-Curtelli B, Tong W, Klang M, Schwartz L, Richardson S, Rosa E, et al.: Phase I clinical trial of histone deacetylase inhibitor: suberoylanilide hydroxamic acid administered intravenously. Clin Cancer Res 2003, 9(IO Pt I):3578-3588.

28. Giles F, Fischer T, Cortes J, Garcia-Manero G, Beck J, Ravandi F, Masson E, Rae $P$, Laird G, Sharma S, et al.: A phase I study of intravenous LBH589, a novel cinnamic hydroxamic acid analogue histone deacetylase inhibitor, in patients with refractory hematologic malignancies. Clin Cancer Res 2006, I 2( I 5):4628-4635.

29. Tumber A, Collins LS, Petersen KD, Thougaard A, Christiansen SJ, Dejligbjerg M, Jensen PB, Sehested M, Ritchie JW: The histone deacetylase inhibitor PXD I0I synergises with 5-fluorouracil to inhibit colon cancer cell growth in vitro and in vivo. Cancer Chemother Pharmacol 2007, 60(2):275-283.

30. Zhang QL, Wang L, Zhang YW, Jiang $X X$, Yang $F, W u ~ W L$, Janin $A$, Chen Z, Shen ZX, Chen SJ, et al.: The proteasome inhibitor bortezomib interacts synergistically with the histone deacetylase inhibitor suberoylanilide hydroxamic acid to induce T-leukemia/lymphoma cells apoptosis. Leukemia 2009, 23(8): I507-14.

3I. Pitts TM, Morrow M, Kaufman SA, Tentler JJ, Eckhardt SG: Vorinostat and bortezomib exert synergistic antiproliferative and proapoptotic effects in colon cancer cell models. Mol Cancer Ther 2009, 8(2):342-349.

32. Frew AJ, Lindemann RK, Martin BP, Clarke CJ, Sharkey J, Anthony DA, Banks KM, Haynes NM, Gangatirkar P, Stanley K, et al.: Combination therapy of established cancer using a histone deacetylase inhibitor and a TRAIL receptor agonist. Proc Natl Acad Sci USA 2008, 105(32): I|317-||322.

33. Zhang W, Peyton M, Xie Y, Soh J, Minna JD, Gazdar AF, Frenkel EP: Histone deacetylase inhibitor romidepsin enhances antitumor effect of erlotinib in non-small cell lung cancer (NSCLC) cell lines. J Thorac Oncol 2009, 4(2): 161-166.

34. Edwards A, Li J, Atadja P, Bhalla K, Haura EB: Effect of the histone deacetylase inhibitor LBH589 against epidermal growth factor receptor-dependent human lung cancer cells. Mol Cancer Ther 2007, 6(9):25I5-2524.

35. Wilson PM, Fazzone W, LaBonte MJ, Deng J, Neamati N, Ladner RD: Novel opportunities for thymidylate metabolism as a therapeutic target. Mol Cancer Ther 2008, 7(9):3029-3037.

36. Wilson PM, Fazzone W, Labonte MJ, Lenz HJ, Ladner RD: Regulation of human dUTPase gene expression and p53-mediated transcriptional repression in response to oxaliplatin-induced DNA damage. Nucleic Acids Res 2008, 37(1):78-95.

37. Bolstad BM, Irizarry RA, Astrand M, Speed TP: A comparison of normalization methods for high density oligonucleotide 
array data based on variance and bias. Bioinformatics 2003, I9(2): 185-193.

38. Benjamini $Y$, Hochberg $Y$ : Controlling the false discovery rate: a practical and powerful approach to multiple testing. J $R$ Statist Soc 1995, 57(I):289-300.

39. Livak KJ, Schmittgen TD: Analysis of relative gene expression data using real-time quantitative PCR and the 2(-Delta Delta C(T)) Method. Methods 200I, 25(4):402-408.

40. Beckman KB, Lee KY, Golden T, Melov S: Gene expression profiling in mitochondrial disease: assessment of microarray accuracy by high-throughput Q-PCR. Mitochondrion 2004, 4(56):453-470.

41. George P, Bali P, Annavarapu S, Scuto A, Fiskus W, Guo F, Sigua C Sondarva G, Moscinski L, Atadja P, et al.: Combination of the histone deacetylase inhibitor LBH589 and the hsp90 inhibitor I7-AAG is highly active against human CML-BC cells and AML cells with activating mutation of FLT-3. Blood 2005, I 05(4): I 768-1776.

42. Kelly WK, O'Connor OA, Krug LM, Chiao JH, Heaney M, Curley T, MacGregore-Cortelli B, Tong W, Secrist JP, Schwartz L, et al.: Phase I study of an oral histone deacetylase inhibitor, suberoylanilide hydroxamic acid, in patients with advanced cancer. J Clin Oncol 2005, 23(17):3923-3931.

43. Fakih MG, Pendyala L, Fetterly G, Toth K, Zwiebel JA, Espinoza-Delgado I, Litwin A, Rustum YM, Ross ME, Holleran JL, et al.: A phase I, pharmacokinetic and pharmacodynamic study on vorinostat in combination with 5-fluorouracil, leucovorin, and oxaliplatin in patients with refractory colorectal cancer. Clin Cancer Res 2009, I5(9):3189-3195.

44. Kang JH, Kim MJ, Chang SY, Sim SS, Kim MS, Jo YH: CCAAT box is required for the induction of human thrombospondin-I gene by trichostatin A. J Cell Biochem 2008, I 04(4): I I92-1203.

45. Cicha I, Goppelt-Struebe M: Connective tissue growth factor: Context-dependent functions and mechanisms of regulation. Biofactors 2009, 35(2):200-208.

46. Barbolina MV, Adley BP, Kelly DL, Shepard J, Fought AJ, Scholtens D, Penzes P, Shea LD, Stack MS: Downregulation of connective tissue growth factor by three-dimensional matrix enhances ovarian carcinoma cell invasion. Int J Cancer 2009, I 25(4):816-25.

47. Pai R, Dunlap D, Qing J, Mohtashemi I, Hotzel K, French DM: Inhibition of fibroblast growth factor 19 reduces tumor growth by modulating beta-catenin signaling. Cancer Res 2008, 68(13):5086-5095.

48. Chau BN, Cheng EH, Kerr DA, Hardwick JM: Aven, a novel inhibitor of caspase activation, binds Bcl-xL and Apaf-I. Mol Cell 2000, 6(I):31-40.

49. Carmena M, Earnshaw WC: The cellular geography of aurora kinases. Nat Rev Mol Cell Biol 2003, 4(I I):842-854.

50. Bischoff JR, Anderson L, Zhu Y, Mossie K, Ng L, Souza B, Schryver B, Flanagan P, Clairvoyant F, Ginther C, et al.: A homologue of Drosophila aurora kinase is oncogenic and amplified in human colorectal cancers. Embo J I998, I 7( I I):3052-3065.

5I. Katayama H, Ota T, Jisaki F, Ueda Y, Tanaka T, Odashima S, Suzuki F, Terada $Y$, Tatsuka M: Mitotic kinase expression and colorectal cancer progression. I Natl Cancer Inst 1999, 9 I (I3): I 160-1162.

52. Cha TL, Chuang MJ, Wu ST, Sun GH, Chang SY, Yu DS, Huang SM, Huan SK, Cheng TC, Chen TT, et al.: Dual degradation of aurora $A$ and $B$ kinases by the histone deacetylase inhibitor LBH589 induces G2-M arrest and apoptosis of renal cancer cells. Clin Cancer Res 2009, 15(3):840-850.

53. Zhang XH, Rao M, Loprieato JA, Hong JA, Zhao M, Chen GZ, Humphries AE, Nguyen DM, Trepel JB, Yu X, et al:: Aurora A, Aurora $B$ and survivin are novel targets of transcriptional regulation by histone deacetylase inhibitors in non-small cell lung cancer. Cancer Biol Ther 2008, 7(9): 1388-1397.

54. Tavares TS, Nanus D, Yang X], Gudas LJ: Gene microarray analysis of human renal cell carcinoma: the effects of HDAC inhibition and retinoid treatment. Cancer Biol Ther 2008, 7(10):1607-1618

55. Popat S, Matakidou A, Houlston RS: Thymidylate synthase expression and prognosis in colorectal cancer: a systematic review and meta-analysis. J Clin Oncol 2004, 22(3):529-536.

56. Dusseau C, Murray GI, Keenan RA, O'Kelly T, Krokan HE, McLeod $\mathrm{HL}$ : Analysis of uracil DNA glycosylase in human colorectal cancer. Int J Oncol 200I, 18(2):393-399.
57. Lee JH, Park JH, Jung Y, Kim JH, Jong HS, Kim TY, Bang YJ: Histone deacetylase inhibitor enhances 5 -fluorouracil cytotoxicity by down-regulating thymidylate synthase in human cancer cells. Mol Cancer Ther 2006, 5( I 2):3085-3095.

58. Gabrielli F, Donadel G, Bensi G, Heguy A, Melli M: A nuclear protein, synthesized in growth-arrested human hepatoblastoma cells, is a novel member of the short-chain alcohol dehydrogenase family. Eur J Biochem 1995, 232(2):473-477.

59. Donadel G, Garzelli C, Frank R, Gabrielli F: Identification of a novel nuclear protein synthesized in growth-arrested human hepatoblastoma HepG2 cells. Eur J Biochem |991, 195(3):723-729.

60. Carew JS, Giles FJ, Nawrocki ST: Histone deacetylase inhibitors: mechanisms of cell death and promise in combination cancer therapy. Cancer Lett 2008, 269(I):7-17.

61. Thirumoorthy N, Manisenthil Kumar KT, Shyam Sundar A, Panayappan L, Chatterjee M: Metallothionein: an overview. World J Gastroenterol 2007, I3(7):993-996.

62. Ferrario C, Lavagni P, Gariboldi M, Miranda C, Losa M, Cleris L, Formelli F, Pilotti S, Pierotti MA, Greco A: Metallothionein IG acts as an oncosupressor in papillary thyroid carcinoma. Lab lnvest 2008, 88(5):474-48।

63. Henrique R, Jeronimo $C$, Hoque MO, Nomoto S, Carvalho AL, Costa VL, Oliveira J, Teixeira MR, Lopes C, Sidransky D: MTIG hypermethylation is associated with higher tumor stage in prostate cancer. Cancer Epidemiol Biomarkers Prev 2005, I4(5): 1274- 1278

64. Terragni J, Graham JR, Adams KW, Schaffer ME, Tullai JW, Cooper GM: Phosphatidylinositol 3-kinase signaling in proliferating cells maintains an anti-apoptotic transcriptional program mediated by inhibition of FOXO and non-canonical activation of NFkappaB transcription factors. BMC Cell Biol 2008, 9:6.

65. Tergaonkar V: NFkappaB pathway: a good signaling paradigm and therapeutic target. Int J Biochem Cell Biol 2006, 38(10):1647-1653

66. Bernal-Mizrachi L, Lovly CM, Ratner L: The role of NF-\{kappa\}BI and NF-\{kappa\}B-2-mediated resistance to apoptosis in lymphomas. Proc Natl Acad Sci USA 2006, 103(24):9220-9225.

67. Vig E, Green M, Liu Y, Donner DB, Mukaida N, Goebl MG, Harrington $M A$ : Modulation of tumor necrosis factor and interleukin-Idependent NF-kappaB activity by mPLK/IRAK. J Biol Chem 1999, 274(I 9): I 3077-13084.

68. Pilarsky C, Wenzig M, Specht T, Saeger HD, Grutzmann R: Identification and validation of commonly overexpressed genes in solid tumors by comparison of microarray data. Neoplasio 2004, 6(6):744-750.

\section{Pre-publication history}

The pre-publication history for this paper can be accessed here:

http://www.biomedcentral.com/1755-8794/2/67/prepub

Publish with Biomed Central and every scientist can read your work free of charge

"BioMed Central will be the most significant development for disseminating the results of biomedical research in our lifetime. "

Sir Paul Nurse, Cancer Research UK

Your research papers will be:

- available free of charge to the entire biomedical community

- peer reviewed and published immediately upon acceptance

- cited in PubMed and archived on PubMed Central

- yours - you keep the copyright

Submit your manuscript here:

http://www.biomedcentral.com/info/publishing_adv.asp

BioMedcentral 